
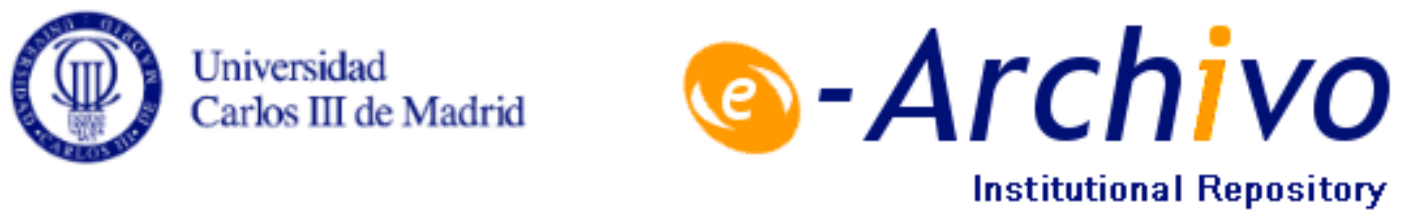

This is a postprint version of the following published document:

Dustmann, C., Schönberg, U.,Stuhler, J. (2017). Labor supply shocks, native wages, and the adjustment of local employment. The Quarterly Journal of Economics, v. 132, n. 1, pp. 435-483. Available in https://doi.org/10.1093/qje/qjw032.

(C) Oxford University Press 


\title{
LABOR SUPPLY SHOCKS, NATIVE WAGES, AND THE ADJUSTMENT OF LOCAL EMPLOYMENT**
}

\author{
Christian Dustmann \\ UTA SCHONBERG \\ JAN STUHLER
}

\begin{abstract}
By exploiting a commuting policy that led to a sharp and unexpected inflow of Czech workers to areas along the German-Czech border, we examine the impact of an exogenous immigration-induced labor supply shock on local wages and employment of natives. On average, the supply shock leads to a moderate decline in local native wages and a sharp decline in local native employment. These average effects mask considerable heterogeneity across groups: while younger natives experience larger wage effects, employment responses are particularly pronounced for older natives. This pattern is inconsistent with standard models of immigration but can be accounted for by a model that allows for a larger labor supply elasticity or a higher degree of wage rigidity for older than for young workers. We further show that the employment response is almost entirely driven by diminished inflows of natives into work rather than outflows into other areas or nonemployment, suggesting that "outsiders" shield "insiders" from the increased competition. JEL Codes: J21, J22, J61, R23. Keywords: Immigration, wage effects, labor supply elasticity, internal migration.
\end{abstract}

\section{INTRODUCTION}

In this article, we revisit the question of how immigration affects the wages and employment of native workers. ${ }^{1}{ }^{1} \mathrm{We}$ exploit a policy that has been implemented 14 months after the fall of the Berlin wall and which allowed Czech workers to seek employment in eligible German border municipalities but denied residence rights, thereby inducing daily commuting across the border. This commuting policy resulted in an almost ideal exogenous labor supply shock that was unexpected, sudden, and of considerable magnitude, averaging to about $10 \%$ of local employment in municipalities closest to the border. The

*Christian Dustmann acknowledges funding through the ERC Advanced Grant 323992-DMEA and by the DFG (DU1024/1-1). Jan Stuhler acknowledges funding from the German National Academic Foundation, the Spanish Ministry of Economy and Competitiveness (MDM2014-0431 and ECO2014-55858-P), and the Comunidad de Madrid (MadEco-CM S2015/HUM-3444).

1. Many papers address this question; see, e.g., Grossman (1982), Altonji and Card (1991), Goldin (1994), Borjas, Freeman, and Katz (1996, 1997), Card (2001), Angrist and Kugler (2003), Borjas (1999, 2003), Manacorda, Manning, and Wadsworth (2012), and Ottaviano and Peri (2012). 
commuting requirement created exogenous variation in the impact intensity at a disaggregated geographic (i.e., municipal) level, which differentiates our work from other studies that use an experimental design. ${ }^{2}$

A further distinguishing feature of our work is the exceptionally high quality data we have available, which is of longitudinal nature and covers the entire workforce. This allows analysis not only of the short-term effects of native responses for detailed groups of workers (e.g., young unskilled natives) but also of different types of employment adjustments. For example, although native employment adjustments in response to an immigrationinduced supply shock are typically interpreted as outflows into nonemployment, they could also result from fewer nonemployed workers entering employment in the affected area. ${ }^{3}$ Similarly, adjustments in local employment need not only stem from movements into and out of nonemployment; they could also be due to geographic movements across local labor markets, a mechanism found to be essential to explain the long-run effects of adverse demand shocks in the United States (see Blanchard and Katz 1992). ${ }^{4}$ To throw more light on these aspects, we provide evidence on the magnitude of each type of response and show how their relative importance varies across worker groups. Thus, the combination of a highly informative policy, a clean identification strategy, and high-quality longitudinal data on potentially affected workers allows us to produce a more complete picture of the effects of labor supply shocks than what so far reported.

Our empirical estimates show that the inflow of Czech workers leads to a moderate decline in average local wages and a

2. See, e.g., Card (1990), Hunt (1992), Carrington and Lima (1996), Friedberg (2001), Glitz (2012), Prantl and Spitz-Oener (2014) and Monras (2015a).

3. Cohen-Goldner and Paserman (2006) distinguish, like us, between the effect of immigration to Israel on inflows and outflows from employment using the rotating panel feature of the Israeli labor force survey.

4. Blanchard and Katz (1992) find that U.S. states that experience an adverse demand shock never fully recover in terms of employment, but that unemployment and wages adjust because of workers moving out of affected states, or leave the labor force (see Yagan 2016). Dao, Furceri, and Loungani (2014) find less net outmigration in more recent periods, in particular in the year after the shock. In the migration literature, the question of whether and to what extent an immigrationinduced labor supply shock may lead some of the existing workforce to relocate remains controversial (see, e.g., Butcher and Card 1991; Filer 1992; Borjas, Freeman, and Katz 1997; Card and DiNardo 2000; Card 2001; and Borjas 2003, 2006). 
sharp decline in local employment of natives. Three years into the policy, a 1 percentage point increase in the overall employment share of Czech workers had decreased local native wages by about 0.13 and local native employment by about $0.9 \% .{ }^{5}$ Both responses were remarkably rapid, with the wage response preceding the full employment response. In light of the strong employment response, it is not surprising that the public reaction to the commuting policy became less favorable, which eventually led to a tightening of the policy.

As is the case for any immigration episode, our findings have to be interpreted in light of the particular policy considered. There are several reasons for why the inflow of immigrants may have led to more adverse effects on natives in ours than in other situations. First, unlike in many other contexts, commuting workers did not live and consume in the affected areas, thus reducing possible demand effects induced by immigrant consumption. ${ }^{6}$ Second, it focuses on the short-term effects of an unexpected and exceptionally large labor supply shock, affecting a region that had not experienced large immigrant inflows or labor supply shocks in the recent past. ${ }^{7}$ Third, the labor supply shock may have been viewed as temporary by firms, making them reluctant to expand capital in response to the shock.

Our decomposition of the overall native employment response into different types of adjustment sheds new insight to the

5. Glitz (2012) and Aydemir and Kirdar (2014), using quasi-natural experiments, also find large employment effects, although their specification is not directly comparable to ours. Using a similar design to ours, Doran, Gelber, and Isen (2015) conclude that the causal impact of extra H-1B visas crowds out employment of other workers in the receiving firm.

6. Despite studying cases when immigrants live and consume in the affected areas, most empirical papers address only the production side and do not investigate the impact of immigrant consumption on native-born wages, although some discuss this possibility. In an early paper, Greenwood and Hunt (1984) suggest that immigration can increase aggregate demand, while Altonji and Card (1991) and Borjas (2013) consider immigrant consumption in their model but not in their empirical analysis. Hercowitz and Yashiv (2002) and Bodvarsson, van den Berg, and Lewer (2008) use model-based approaches to reexamine mass migration to Israel and the Miami boatlift, respectively, and conclude that demand effects may delay or abate wage and employment effects on natives.

7. This distinguishes our border region from, e.g., the Miami labor market analyzed in Card (1990), which had a long history of immigration (with a 35.5\% foreign born population). Card (1990) points out that as a result, the "industry distribution in Miami in the late 1970s was well suited to handle an influx of unskilled immigrants," with "textile and apparel industries particularly prominent" (p. 256). 
interpretation of employment responses to immigration. First, native employment decreases predominantly through reductions in inflows into local employment, whereas outflows from the incumbent native workforce are much smaller. This observation indicates that "outsiders" (i.e., workers not employed in the affected area) bear most of the burden of the labor supply shock and thus shield "insiders" (i.e., workers employed in the affected area) from the adverse effects of the shock. The shielding effect could arise either because "outsiders" are particularly elastic in their employment response or "insiders" are, at least in the short run, protected by partial wage rigidity and firing restrictions. Second, even in the short run, roughly one-third of the local employment response results from geographic movement to and from employment in other areas not affected by the labor supply shock, meaning that it does not necessarily reflect a reduction in the national employment level.

In terms of differential effects by skill, the inflow of Czech workers leads to larger wage and employment declines for unskilled than skilled natives, which, given Czech workers' lower level of skills relative to German workers, is in line with the standard immigration model. Breaking wage and employment responses further out by age group, our results reveal that among skilled workers, natives under 30 suffer the largest wage decline, whereas natives over 50 suffer the largest employment decline, although most Czechs who entered the West German border area were middle aged. This pattern (which we refer to as "perverse" effects) is inconsistent with standard models of immigration but can, as we show, be accounted for by a model that allows for a larger employment response (either due to a larger local labor supply elasticity, or a higher degree of wage rigidity) for older than for young workers. It underscores the need to analyze immigration-induced wage and employment responses jointly, as isolated estimates of wage or employment effects may misrepresent the overall impact of immigration. ${ }^{8}$

8. Piyapromdee (2014) makes a related point by suggesting that a mainly unskilled immigration shock to a particular area may be exacerbated in its effect on unskilled natives if these are relatively immobile. Most papers in the literature focus on wage responses only. Card (1990, 2001, 2007), Altonji and Card (1991), Dustmann, Fabbri, and Preston (2005), Boustan, Fishback, and Kantor (2010), Wagner (2010), and Glitz (2012) investigate wage and employment responses, but not how these responses interact with each other. 


\section{An Equilibrium Model with Heterogeneous Labor Supply AND WAGE RIGIDITIES}

To aid the interpretation of our empirical findings, we commence by setting out a simple model that links immigrationinduced labor supply shifts to the employment and wage responses of natives in the local labor market. We assume that (as it is the case in our empirical application) the local labor market under consideration is small relative to the national labor market. In consequence, the change in equilibrium wages (and native employment) in other areas will be negligible even if natives respond to the labor supply shock by moving away from affected areas. We start out with a fully competitive labor market as a benchmark, and allow for wage rigidities in a second step. One important distinguishing feature of our model relative to other models is that we allow the labor supply responses of natives, or the degree of wage rigidity, to vary across skill or other demographic groups.

\section{II.A. Basic Set-up}

1. Production. Supposing that output $Q$ in a specific area is produced by combining labor $L$ and capital $K$ according to a Cobb-Douglas production function, then

$$
Q=A K^{\alpha} L^{1-\alpha} .
$$

Here, labor $L$ is a CES aggregate of unskilled $(U)$ and skilled $(S)$ labor $L_{g}, g=U, S$ :

$$
L=\left[\theta_{U} L_{U}^{\beta}+\theta_{S} L_{S}^{\beta}\right]^{\frac{1}{\beta}},
$$

where $\theta_{U}+\theta_{S}=1$, and the elasticity of substitution between the two skill groups equals $\sigma=\frac{1}{1-\beta}$, with $\beta \leqslant 1$.

Within each skill group $g$, natives (or incumbents, denoted by $L_{g}^{N}$ ) and immigrants (or entrants, denoted by $L_{g}^{I}$ ) are perfect substitutes in production, so that $L_{g}=L_{g}^{N}+L_{g}^{I} \cdot{ }^{9}$ Without loss of

9. We investigate below wage- and employment responses for different skill groups to the overall labor supply shock induced by the commuting policy. This means that in our estimation procedure, we do not allocate Czech workers to skill groups based on their observed skills. Whether Czechs compete with natives in a particular skill group (and therefore are substitutes for them) will be part of the parameter that we estimate. 
generality, we further assume that (as in our empirical setting) there are no immigrants in the base period.

2. Labor demand. Assuming that firms are price takers in the labor, capital and product market and normalizing the price of the output good to 1 , firms choose labor and capital such that marginal costs equal the marginal products of labor and capital:

$$
\begin{aligned}
\log w_{g}= & \log [(1-\alpha) A]+\alpha[\log K-\log L] \\
& +\log \theta_{g}+(\beta-1)\left[\log L_{g}-\log L\right], \\
\log r= & \log \alpha A+(\alpha-1)[\log K-\log L] .
\end{aligned}
$$

Suppose that the local supply of capital depends on the rental price of capital in the local labor market under consideration $(r)$ and on rental prices in other local markets $\left(\boldsymbol{r}^{\prime}\right), K=h\left(r, \boldsymbol{r}^{\prime}\right)$, and let $\lambda$ denote the inverse of the local elasticity of capital with respect to its price $r$ (i.e., $\frac{1}{\lambda}=\frac{\partial h}{\partial r} \frac{r}{h}$ ).

In Online Appendix A.I, and following Dustmann, Frattini, and Preston (2013), we derive the firm's change in the demand of native workers (net of immigrant workers) from skill group $g$, $d \log L_{g}^{N}$, to a total immigration-induced labor supply shock relative to native equilibrium employment in the base period (in head counts), $d I=\frac{d L^{I}}{L^{N}}$, resulting in

$$
\frac{d \log L_{g}^{N}}{d I}=\frac{\varphi s_{g}+(\beta-1) s_{g^{\prime}}}{(\beta-1) \varphi} \frac{d \log w_{g}}{d I}-\frac{(\varphi-(\beta-1)) s_{g^{\prime}}}{(\beta-1) \varphi}
$$

$$
\times \frac{d \log w_{g^{\prime}}}{d I}-\frac{\pi_{g}^{I}}{\pi_{g}^{N}},
$$

where $g^{\prime}$ denotes the other skill group, $\varphi=-\frac{\alpha \lambda}{1-\alpha+\lambda}$ is the slope of the aggregate labor demand curve, $\pi_{g}^{N}$ and $\pi_{g}^{I}$ denote the share of workers of skill group $g$ (in head counts) among immigrants and natives (i.e., $\pi_{g}^{N}=\frac{L_{g}^{N}}{L_{U}^{N}+L_{S}^{N}}$ and $\pi_{g}^{I}=\frac{L_{g}^{I}}{L_{U}^{I}+L_{S}^{I}}$ ), and $s_{g}$ denotes the contribution of labor type $g$ to the total labor aggregate (see Online Appendix A.I for details).

Suppose that $g$ indexes unskilled labor and $g^{\prime}$ skilled labor and that immigration is predominantly unskilled (i.e., $\frac{\pi_{g}^{I}}{\pi_{g}^{I}}>1$ ). Equation (2) first illustrates that in the absence of any wage 
response to immigration (i.e., $\frac{d \log w_{g}}{d I}=\frac{d \log w_{g^{\prime}}}{d I}=0$ ), unskilled native employment declines by the rate $\frac{\pi_{U}^{I}}{\pi_{U}^{N}}$, the relative density of immigrants to natives among unskilled workers. Equation (2) further highlights that a decline in the wage of unskilled labor in response to immigration (i.e., $\frac{d \log w_{U}}{d I}<0$ ) will dampen the employment response of the unskilled, as both the slope of the demand curve $\varphi$ and $\beta-1$ are negative (i.e., $\frac{\varphi s_{g}+(\beta-1) s_{g^{\prime}}}{(\beta-1) \varphi}<0$ ). Further, the impact of the overall immigration shock on skilled wages is ambiguous (i.e., $\left.\frac{d \log w_{g^{\prime}}}{d I} \lesseqgtr 0\right) .{ }^{10}$ Similarly, the impact of an increase in skilled wages on the demand for unskilled native labor is also

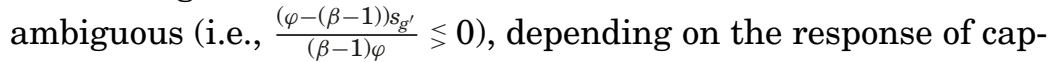
ital and the degree of substitutability between the different input factors.

\section{II.B. Equilibrium}

1. Competitive Equilibrium with Fully Flexible Wage. In a competitive equilibrium, quantities supplied must equal quantities demanded, and the intersection of the demand curve given by equation (2) and the supply curve determine the skill-specific and aggregate wages and employment in the local labor market. Using $N_{g}$ to denote the (fixed) number of natives who could potentially supply labor to the local labor market, the local labor supply function for skill group $g$ is

$$
L_{g}=L_{g}^{I}+L_{g}^{N}=L_{g}^{I}+N_{g} f_{g}\left(w_{g}, \boldsymbol{w}_{g}^{\prime}\right),
$$

where immigrants (i.e., new entrants) are (as in Borjas 2013) assumed to supply their labor inelastically, but the local labor supply of natives (i.e., incumbents) depends on skill-specific wages in the market under consideration $\left(w_{g}\right)$ and other local labor markets $\left(\boldsymbol{w}_{g}^{\prime}\right)$. The local labor market elasticity for natives, which we allow to vary by skill group, is then given by $\eta_{g}=\frac{\partial\left(N_{g} f_{g}\right)}{\partial w_{g}} \frac{w_{g}}{N_{g} f_{g}}$. It should be noted that this elasticity differs from the elasticities typically estimated in the labor supply literature, which measure the response of individuals to changes in net wages affecting the

10. There are two opposing forces: skilled wages decrease because of imperfect elasticity of capital, but increase because of imperfect substitution between skilled and unskilled workers. 
national labor market. ${ }^{11} \mathrm{We}$, in contrast, consider a manipulation of local labor market conditions to which natives may respond not only by moving into and out of nonemployment but also by moving away from, or no longer moving into, the area. ${ }^{12}$ The local labor supply elasticity therefore summarizes various potential adjustment mechanisms, such as the internal migration of workers between areas, or entries into and exits from the labor force. These adjustment margins may have different importance for different types of workers and thus help explain why some groups respond more elastically than others. For instance, the employmentto-unemployment transitions may be particularly important for older workers entitled to generous unemployment and pension benefits.

From the labor supply function (3), it follows that

$$
d \log w_{g}=\frac{1}{\eta_{g}} d \log L_{g}^{N} .
$$

By substituting this expression (for both skill groups) into equation (2) and rearranging, we derive the equilibrium employment response as (see Online Appendix A.II for details):

$$
d \log L_{g}^{N}=\frac{\left.\eta_{g}(\beta-1)\left[\frac{\pi_{g}^{I}}{\pi_{g}^{N}}\left(1-\varphi \eta_{g^{\prime}}\right)-\Pi 1-\frac{\varphi}{\beta-1}\right)\right]}{1-(\beta-1)\left[\eta_{g}\left(1+s_{g} \phi\right)+\eta_{g^{\prime}}\left(1+s_{g^{\prime}} \phi\right)-\eta_{g} \eta_{g^{\prime}} \varphi\right]} d I .
$$

Because $\beta \leqslant 1$, and $\phi=\frac{\varphi}{\beta-1}-1$, the denominator in (5) will always be positive. The numerator is the difference between the relative density of immigrants to natives in skill group $g, \frac{\pi_{g}^{I}}{\pi_{g}^{N}}$ and the (weighted) average of these densities in the different skill groups, $\Pi=s_{U} \frac{\pi_{U}^{I}}{\pi_{U}^{N}}+s_{S} \frac{\pi_{S}^{I}}{\pi_{S}^{N}}$, both weighted by expressions that depend on the elasticity of capital supply $(\varphi)$ and the supply elasticity of the other labor type $\left(\eta_{g^{\prime}}\right)$. Thus, when $\beta<1$, the impact of a supply shock on native

11. See, e.g., MaCurdy (1981) and Chetty et al. (2011) who estimate the labor supply elasticity at the intensive margin or Blundell, Bozio, and Laroque (2013) who estimate the elasticity at the extensive margin.

12. Heterogeneity in geographical mobility may have different reasons. For instance, Notowidigdo (2013) shows that labor demand shocks may lead to differential mobility responses for low and high skilled workers because they lead to changes in house prices and transfer payments. 
employment will be negative for skill group $g$ if the weighted intensity of immigration in that skill group (first term in brackets) exceeds an appropriately weighted average of immigration intensity across all skill groups (second term in brackets).

In the standard case of a homogenous local labor supply elasticity (i.e., $\eta_{U}=\eta_{S}=\eta$ ), equations (4) and (5) imply that both the wages and the employment of the skill group that experiences the larger migration-induced supply shock (i.e., the group for which $\left.\frac{\pi_{g}^{I}}{\pi_{g}^{N}}>\Pi\right)$ will decline relative to the wages and employment of the other group. These implications also hold for more general production functions than equation (1), such as functions that distinguish many skill groups (see, e.g., Dustmann, Frattini, and Preston 2013) or allow for a third nest within skill groups (see, e.g., Card and Lemieux 2001; Borjas 2003).

If, in contrast, the local labor supply elasticity varies across groups, then the wages of the skill group for which immigration is relatively intensive may increase relative to the other skill group, as can be shown by considering the relative wage effects:

(6) $d \log w_{S}-d \log w_{U}=\frac{(\beta-1)\left[\frac{\pi_{S}^{I}}{\pi_{S}^{N}}\left(1-\varphi \eta_{U}\right)-\frac{\pi_{U}^{I}}{\pi_{U}^{N}}\left(1-\varphi \eta_{S}\right)\right]}{1-(\beta-1)\left[\eta_{S}\left(1+s_{S} \phi\right)+\eta_{U}\left(1+s_{U} \phi\right)-\eta_{U} \eta_{S} \varphi\right]} d I$. Supposing that migration is predominantly unskilled (i.e., $\frac{\pi_{S}^{I}}{\pi_{S}^{N}}<$ $\left.\frac{\pi_{U}^{I}}{\pi_{U}^{N}}\right)$ and that the local labor supply of the unskilled is elastic relative to that of the skilled (i.e., $\eta_{U}$ is large relative to $\eta_{S}$ ), then the relative employment effect is amplified and the relative wage effect muted compared to the case of a homogenous local labor supply elasticity. Provided that capital is not fully elastic $(\varphi<0)$ and some skilled migrants enter the local labor market $\left(\pi_{S}^{I}>0\right)$, the wages of the unskilled may even increase relative to those of the skilled. At the same time, employment of the unskilled will strongly decline relative to that of skilled natives. Thus, in these "perverse" cases, relative wage and employment effects have the opposite signs. This observation emphasizes the need to investigate immigration-induced wage and employment responses jointly to avoid a misleading picture of immigration's overall labor market effects. It should further be noted that in the case of two skill groups, such an effect will only be observable when capital is not perfectly elastic; that is, $\varphi<0$. If an additional skill group is added, perverse effects can occur even when the capital supply is fully elastic (see Online Appendix A.III). 
2. Wage Rigidities. Our analysis so far assumes that wages are fully flexible. However, in reality wages may, at least in the short run, be partially downward rigid, and the degree of wage rigidity may vary across skill groups (see, e.g., Card, Kramarz, and Lemieux 1999). For instance, skilled workers may be more likely to be covered by long-term contracts than unskilled workers, preventing firms from immediately cutting skilled wages. ${ }^{13}$ Next, we allow for partially rigid wages, and further allow the degree of wage rigidity to be different for skilled and unskilled workers.

Let $\overline{d \log w_{g}}$ denote the wage change, constrained by labor market institutions or private contractual arrangements, by which wages for skill group g may decline at most. The smaller (in absolute terms) $\overline{d \log w_{g}}$, the more rigid wages are. Provided that wages cannot fall by as much as the equilibrium wage response given by equations (4) and (5) for both skill groups, the economy is demand-side constrained and there will be an abundance of native workers who would like to work for the current wage rate, but cannot find a job, and the employment response of natives is given by equation (2) where wage responses $d \log w_{g}$ are determined exogenously by the degree of wage rigidity $\overline{d \log w_{g}}$.

Heterogeneity in the degree of wage rigidity provides, in addition to heterogeneity in labor supply responses, an explanation for "perverse" effects in which the group that experiences the greatest shock needs not be the group that suffers the largest wage or employment decline. ${ }^{14}$

\section{BACKGROUND AND DATA}

\section{III.A. Commuter Policy}

Our analysis takes advantage of a commuting policy (Grenzgängerregelung), triggered by the fall of the Iron Curtain and implemented by the German government in 1991, that allowed workers from the neighboring Czech Republic to seek employment in German districts along the German-Czech border (see

13. Angrist and Kugler (2003) point out that labor market rigidities, while protecting some native workers from immigrant competition, can increase negative employment effects. They provide evidence that migration creates higher employment responses in countries with more rigid institutions.

14. Wages of skilled workers are more downward rigid than those of unskilled workers if $\frac{\overline{d \log w_{s}}}{d \log w_{s}}<\frac{\overline{d \log w_{u}}}{d \log w_{u}}$, where $d \log w_{g}$ is the equilibrium wage response in the case of fully flexible wages given by equations (4) and (5). 
also Moritz 2011 who was the first to investigate the labor market effects of that policy). Although allowed to work in Germany, these workers were not granted residence, forcing them to commute on a daily basis between their home country and their workplace in Germany, an aspect that our empirical analysis exploits (see Section IV.B). ${ }^{15}$ The policy was otherwise nonrestrictive. Work permits were formally granted for up to two years and could be renewed after that. ${ }^{16}$

This particular commuting scheme was part of a larger scheme for the legal employment of foreign nationals in Germany announced in September 1990 and implemented on January 1, 1991, one year after the fall of the Berlin wall. The intention of the scheme's various provisions was to facilitate the recruitment of foreign workers in a time of increased labor demand following German reunification. ${ }^{17}$ For example, a similar commuting scheme applied to Germany's second Eastern neighbor, Poland, and nondiscriminately covered all German districts sharing a border with either Poland or the Czech Republic. The overall policy set up ensures that the commuting scheme examined here was exogenous to the economic conditions in the areas covered. We provide more details on the policy in Online Appendix B.

Figure I maps the region affected by the scheme, which comprises 21 districts within an approximate 80 kilometer band from the Czech-German border. Some of these districts, however, are close to the former East and West German border and may thus have been affected after the 1990 reunification by commuters from East Germany, where wages were lower. Hence, to avoid any contamination of our experiment, we exclude districts located within approximately 80 kilometers of the former East and West German border (although our results remain robust to less

15. The requirement to commute was enforced via various channels. First, workers that entered employment under the commuting scheme had to apply for a special type of permit, the Grenzgängerkarte, which reflected the worker's conditional residence status. Second, in line with the German requirement that all residents register with the local registry office, a double registration was required by which both tenants and landlords had to submit information, making it impossible for Czech commuters to legally rent a home in Germany.

16. Commuting requirements play also a central role in Angrist (1996) and Mansour (2010) who study the labor market response to exogenous changes in the commuting pattern of Palestinian day workers during the First and Second Intifada.

17. See "Anwerbestoppausnahme-Verordnung" (1990), Bundesgesetzblatt, Jahrgang 1990, Teil I. 


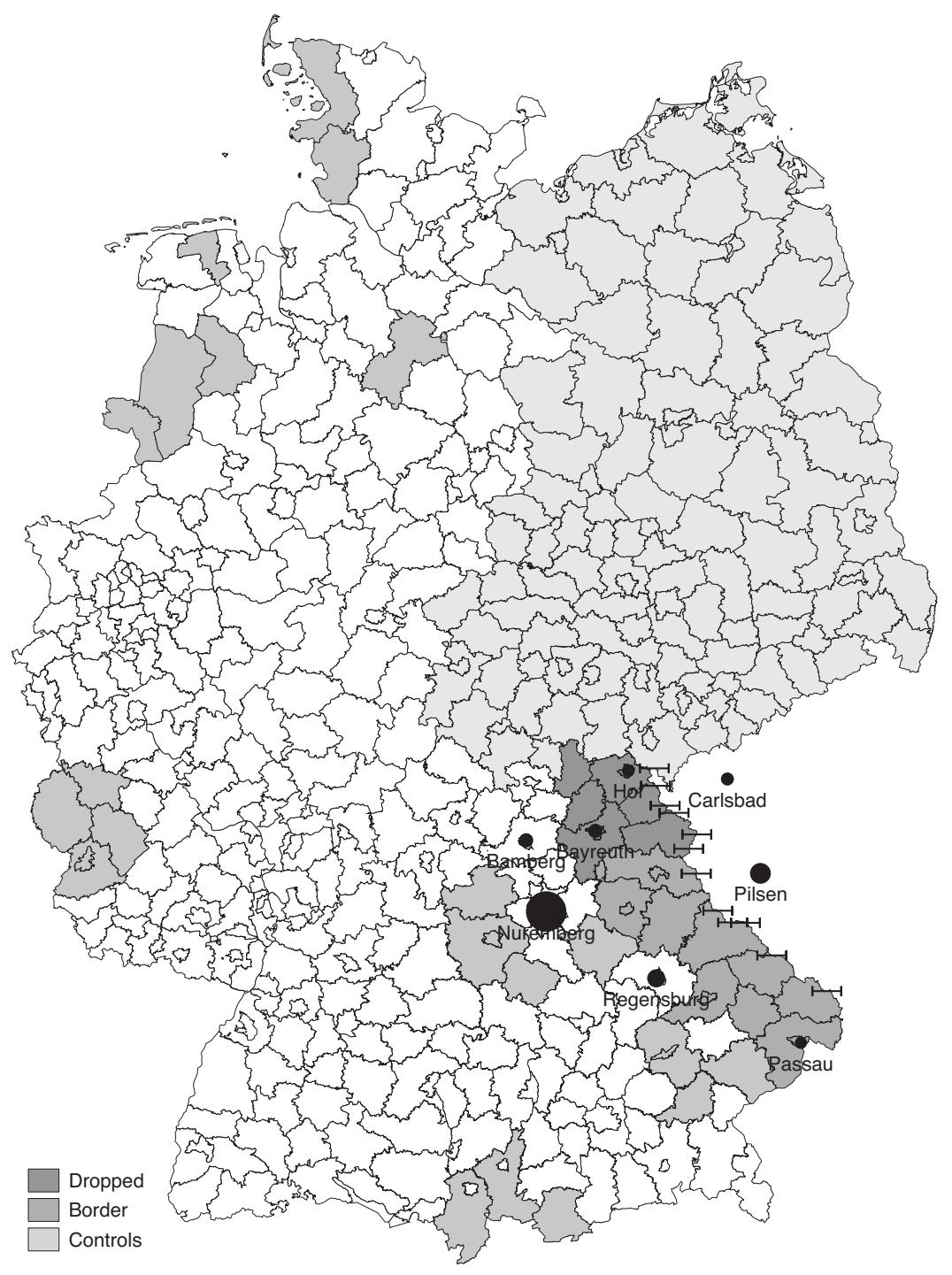

FIGURE I

\section{Border Region}

The map shows districts eligible under the commuting policy (medium gray and dark gray), matched inland control districts (light gray), and other districts in West (white) and former East (gray) Germany. Eligible districts close to the inner German border (dark gray) are dropped in the analysis. The map also shows crossings along and cities near the Czech-German border. 
Characteristics of Treated, Inland and Matched Control Districts in 1989

\begin{tabular}{llll}
\hline \hline & & \multicolumn{2}{c}{ West } \\
& Border & $\begin{array}{c}\text { Control } \\
\text { districts }\end{array}$ \\
\hline Skill & & & \\
$\quad$ Low (no postsecondary education) & 0.274 & 0.229 & 0.244 \\
$\quad$ Medium (apprenticeship or equivalent) & 0.695 & 0.703 & 0.723 \\
$\quad$ High (university or college) & 0.030 & 0.069 & 0.034 \\
Age & & & \\
$\quad$ Below 30 & 0.434 & 0.351 & 0.420 \\
30 to 49 & 0.410 & 0.454 & 0.412 \\
$\quad$ 50 and above & 0.157 & 0.195 & 0.168 \\
Female & 0.411 & 0.401 & 0.414 \\
Foreign & 0.025 & 0.081 & 0.035 \\
Mean log wages (censored) & 3.881 & 4.055 & 3.879 \\
Share censored & 0.023 & 0.048 & 0.027 \\
No. districts & 13 & 327 & 24 \\
No. workers & 335,042 & $21,173,830$ & 726,536 \\
\hline \hline
\end{tabular}

Note. The table compares average characteristics (weighted by employment level) of workers in eligible districts in the border region, in all other West-German districts and in matched control districts (see Figure I) in 1989, one year prior to the immigration-induced labor supply shock. The wage variable refers to the average wage earned per day of the employment relationship and is right-censored at the social security limit.

Data Source: German Social Security Data, 1989.

conservative choices). As Figure I shows, this exclusion leaves a rural region of 13 districts, or 291 municipalities, referred to hereafter as the "border region," which contains various small but no large cities. As Table I illustrates, its local labor market at that time was characterized by a comparatively small share of highly skilled workers with university degrees, a young workforce, low wages, and a low share of preexisting immigrants.

The introduction of the commuting scheme in January 1991 led to a substantial and rapid inflow of Czech workers into the border region, whose employment shares in border and selected control districts (defined in Section IV.B) are plotted in Figure II. By June 1992, the share of Czech nationals in the border region had increased from close to zero to about $3 \%$ and on average to about $10 \%$ in municipalities closest to the border. The employment share of Czech nationals in control districts, in contrast, being unaffected by the commuting scheme, remained negligible. As Figure II also shows, the share of Czech workers remained stable from 1992 to 1993 and decreased thereafter, partly because of a stricter interpretation of the commuting scheme in later years, which was caused by allegations that the large Czech inflows into 


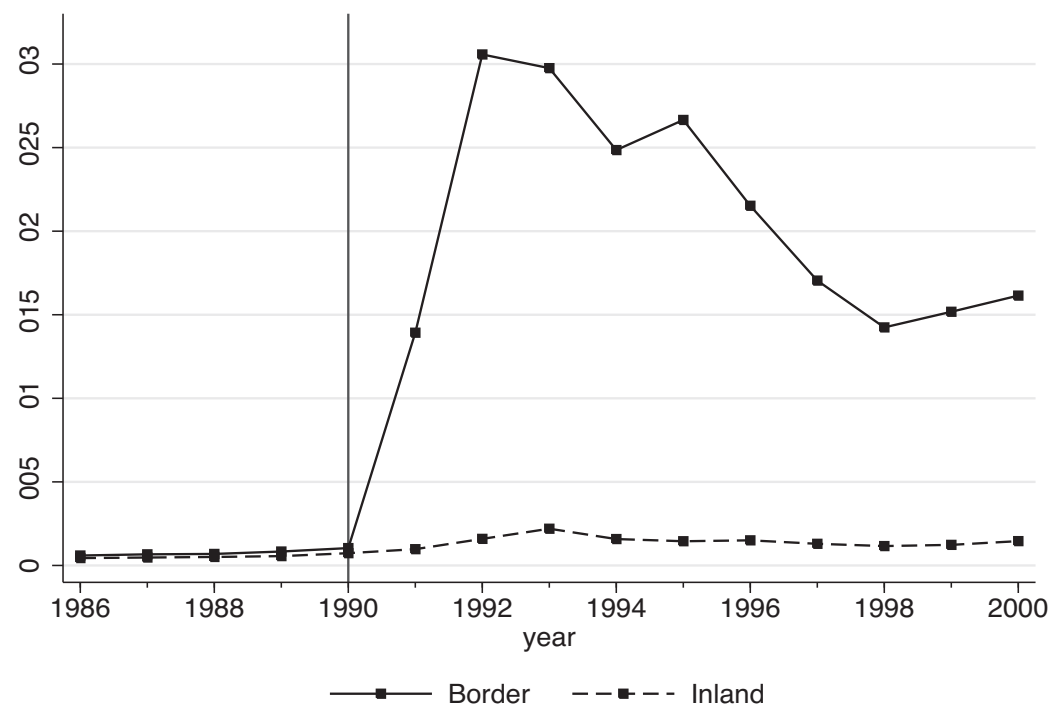

FIGURE II

Employment Shares of Czech nationals: Border vs Inland

The figure plots the share of Czech workers in local employment in the border region and in matched control districts (see Figure I) before and after the commuting policy came into effect in 1991. Data Source: German Social Security Records, eligible border region and matched control districts, 1986 to 2000.

the border region had led to a worsening of conditions for native workers. Hence, in the empirical analysis, we focus on the immediate wage and employment effects of the labor supply shock up until 1993 because the "reverse experiment" of subsequent decline in the share of Czech nationals from 1994, albeit interesting, is potentially endogenous to local labor market conditions.

Table II provides descriptive statistics for both the existing stock of workers in the border region in 1989 (i.e., before the entry of workers from the Czech Republic) and for Czech nationals, with their characteristics as of 1992. According to the table, Czech workers were far more likely to be unskilled (i.e., had no post-secondary degree) than the existing workforce $(50.5 \%$ vs $27.6 \%)$ and more likely to fall into the 30 to 49 age group $(61.9 \%$ vs $40.8 \%$ ), with a much lower share of workers over 50 (3.7\% vs $15.7 \%)$. The Czech nationals were also predominantly male, and in terms of concentration, overrepresented in construction, the hotel 
TABLE II

Characteristics of Czech and Non-Czech Nationals in the Border Region

\begin{tabular}{|c|c|c|}
\hline Panel A: Non-Czechs vs Czechs & $\begin{array}{c}\text { Non-Czech } \\
\text { (1989) }\end{array}$ & $\begin{array}{l}\text { Czech } \\
\text { (1992) }\end{array}$ \\
\hline \multicolumn{3}{|l|}{ Skill distribution } \\
\hline Unskilled (no postsecondary education) & 0.276 & 0.505 \\
\hline Skilled (apprenticeship or equivalent, university) & 0.724 & 0.495 \\
\hline \multicolumn{3}{|l|}{ Age distribution } \\
\hline Below 30 & 0.435 & 0.344 \\
\hline $30-49$ & 0.408 & 0.619 \\
\hline 50 and above & 0.157 & 0.037 \\
\hline \multicolumn{3}{|l|}{ Age distribution: unskilled } \\
\hline Below 30 & 0.500 & 0.370 \\
\hline $30-49$ & 0.290 & 0.593 \\
\hline 50 and above & 0.209 & 0.037 \\
\hline \multicolumn{3}{|l|}{ Age distribution: skilled } \\
\hline Below 30 & 0.410 & 0.317 \\
\hline $30-49$ & 0.453 & 0.646 \\
\hline 50 and above & 0.137 & 0.037 \\
\hline Share female & 0.411 & 0.163 \\
\hline \multicolumn{3}{|l|}{ Industries } \\
\hline Public sector & 0.171 & 0.021 \\
\hline Pit and quarry & 0.027 & 0.048 \\
\hline Wood processing & 0.032 & 0.074 \\
\hline Construction & 0.099 & 0.249 \\
\hline Hotels and restaurants & 0.031 & 0.092 \\
\hline No. workers & 332,785 & 9,996 \\
\hline \multicolumn{3}{|l|}{ Panel B: Relative Wage Gap Czechs vs Non-Czechs (1992) } \\
\hline & Coeff. & S.E. \\
\hline (i) Municipality fixed effects & -0.302 & $(0.003)$ \\
\hline (ii) Occupation $\times$ firm fixed effects & -0.214 & $(0.006)$ \\
\hline (iii) Occupation $\times$ firm $\times$ tenure fixed effects & -0.136 & $(0.006)$ \\
\hline No. workers & \multicolumn{2}{|c|}{267,756} \\
\hline
\end{tabular}

Note. Panel a compares the characteristics of Czech commuters (in 1992) against the preexisting, non-Czech workforce (in 1989). Panel b reports the log-wage gap between Czech and Non-Czech workers in the border region in 1992. The wage variable refers to the average wage earned per day of the employment relationship and is right-censored at the social security limit. Following Dustmann, Ludsteck, and Schoenberg (2009), we impute wages under the assumption that the error term is normally distributed while allowing for a different residual variance by gender as well as by district. All regressions control for age, age squared, sex, and education (distinguishing between 3 education groups). Row (i) additionally controls for municipality fixed effects. Row (ii) further adds 3-digit occupation $\times$ firm fixed effects, while Row (iii) controls for 3-digit occupation $\times$ firm $\times$ tenure fixed effects. Robust standard errors in parentheses.

Data Source: German Social Security Records, eligible border region, 1989 and 1992.

and restaurant industry, and wood processing and manufacturing, and underrepresented in the public sector. On average, Czech nationals earned $0.302 \log$ points lower wages than natives, conditional on age, sex, and education (row (i) of Panel B). The 
wage gap between Czech and German nationals declines within detailed occupation and firm groups (0.214; row (ii)) and reduces further if the Czech and native worker were hired in the same year (0.136; row (iii)). This remaining difference in wages may be due to Czechs' marginal productivity being lower than that of natives, due to, for example, lower returns to unobserved characteristics such as experience accumulated at home or lack in language proficiency.

\section{III.B. Data}

Our data come from over two decades of German Social Security Records (from 1980 to 2001), which include all men and women covered by the social security system, excluding civil servants, the self-employed, and military personnel. ${ }^{18}$ Three characteristics make this data set well suited for our analysis. First, the large sample size allows us to obtain fairly precise estimates of immigration on wages and employment even for detailed subgroups, although only a relatively small local area is affected by immigrant inflows. Second, the longitudinality of the data allows us to investigate whether the employment effects are driven by an increased outflow of workers into other areas or non- or unemployment, or by a decreased inflow of workers into the local labor market, a dynamic so far underexplored in the literature. Third, in addition to information on education, age, and other individual characteristics, the data include the citizenship of every employed individual, which allows identification of all Czech workers working in Germany but living in the Czech Republic. As a result, in our analysis, sampling error in the migration-induced supply shock, which attenuates estimates of its impact on native labor market outcomes (Aydemir and Borjas 2011), is close to zero.

Because our data set is constructed to observe each individual as of June 30 each year, each individual's employment status also refers to this date. The wage variable, in contrast, records the average daily wage in the employment spell that contains the reference date. ${ }^{19}$ As is typically the case with social security data, our

18. In $2001,77.2 \%$ of all workers in the German economy were covered by social security and are hence recorded in the data (Federal Employment Agency, 2004).

19. Because employers are required to update records only at the end of each year, this variable may also capture wage changes that occurred from June 30 to December of the same year. 
wage variable is right-censored at the social security limit, which in our sample affects only about $3 \%$ of all observations. Following Dustmann, Ludsteck, and Schönberg (2009), we impute censored wages under the assumption that the error term is normally distributed while allowing for a different residual variance by gender as well as by district. Information on districts or municipalities in our data refer to the individual's place of work and not her place of residence.

We distinguish two skill groups: unskilled workers who enter the labor market without postsecondary education and skilled workers who have completed an apprenticeship scheme or equivalent or graduated from a university. ${ }^{20}$ This classification is particularly meaningful in the German context in which many apprenticeship jobs educate for professions that require college degrees in Anglo-Saxon countries (e.g., medical assistant or bank clerk). We do not report separate results for university graduates because their share in the border region in 1990 was less than 5\%. Within each of these skill groups, we also distinguish three age groups: younger than 30,30 to 49 , and 50 and older. We further restrict the analysis to individuals aged between 18 and 65 and exclude irregular, marginal, and seasonal employment, as well as individuals undergoing apprenticeship training whose wages may not reflect their productivity. Our analysis of employment effects is thus based on regular full- and part-time workers, with part-time work ( $>30$ hours per week) down-weighted into full-time equivalent units by 0.67 (18-30 hours) or 0.5 ( $<18$ hours). Our wage analysis is based on full-time employees only.

\section{EMPIRICAL STRATEGY}

In this section, we first explain how our main regression equations relate to the theoretical model presented in Section II and then describe our procedures for estimation and identification.

20. To improve the consistency of the education variable in our data set, we impute missing values using past and future values of the education variable (see Fitzenberger, Osikominu, and Völter 2006). The imputed education variable is missing for $3.9 \%$ of observations in the overall data, and $2 \%$ of sampled observations in the border region. We classify these individuals as unskilled, although doing so has little impact on our findings. 


\section{IV.A. Effect of Immigration on Wages and Employment}

Corresponding to our theoretical setup, our basic estimation equation regresses the change in log wages of natives $(N)$ in skill group $g$, age group $s$, and area $j$ between two periods, $t$ and $k$, $\Delta \ln w_{g s, j}$, or the percentage change in native local employment, $\Delta L_{g s, j}^{N}$, on the total inflow of Czech workers between 1990 and 1992 as a share of total employment in that area in $1990, \Delta C_{j}^{92-90}$ :

$$
\Delta \ln w_{g s, j}=\alpha_{g s}+\beta_{g s} \Delta C_{j}^{92-90}+u_{g s, j}
$$

and

$$
\Delta L_{g s, j}^{N}=\gamma_{g s}+\delta_{g s} \Delta C_{j}^{92-90}+v_{g s, j},
$$

where

$$
\Delta C_{j}^{92-90}=\frac{L_{j 92}^{C z e c h}-L_{j 90}^{C z z c h}}{L_{j 90}^{N}+L_{j 90}^{f o r e i g n}} \text { and } \Delta L_{g s, j}^{N}=\frac{L_{g s, j t}^{N}-L_{g s, j k}^{N}}{L_{g s, j k}^{N}} .
$$

Equations (7) and (8) are written in first differences to eliminate time-constant area, skill and age group fixed effects while allowing for skill and age group-specific growth rates in wages and employment, $\alpha_{g s}$ and $\gamma_{g s}$. The parameters of interest are $\beta_{g s}$ and $\delta_{g s}$, which measure the impact of the total inflow of Czech workers between 1990 and 1992 on the percent change in wages and employment of native workers in skill group gs in area $\mathrm{j}$ between the two time periods (specified in Section IV.B below). ${ }^{21}$ If wages are fully flexible, these parameters correspond to the expressions derived in equations (4) and (5). If wages are partially rigid, the wage response $\beta_{g s}$ is determined exogenously by the degree of rigidity (see Section II.B) and the employment response $\delta_{g s}$ is given by equation (2), Section II.A. It should be noted that in contrast to the change in the local employmentto-population ratio used in many extant studies (see, e.g., Altonji and Card 1991; Dustmann, Fabbri, and Preston 2005; Boustan,

21. We scale the inflow of Czechs between 1990 and 1992 by total (including foreign) employment in 1990, as the supply shock may displace not only native but also pre-shock foreign workers. This choice has little consequences for our estimates as the share of foreign workers was small in 1990. It ensures that the coefficient $\delta_{g s}$ will be equal to -1 under full displacement, where every Czech worker displaces either a native or foreign resident worker in proportion to the employment share of each group. 
Fishback, and Kantor 2010; Smith 2012), the employment response in equation (8) captures, in line with our theoretical set up, employment movements across areas in addition to movements from and to un- or nonemployment-which may be one reason why we detect larger employment responses than typically estimated in the literature. ${ }^{22}$

The coefficients $\beta_{g s}$ and $\delta_{g s}$ identify the total wage and employment effect of immigration, taking into account the indirect effects of immigration through complementarities across skill and age cells and across capital and labor, and answer the question: "What is the overall effect of immigration on (local) wages and employment of a particular native skill-age group." 23 They conceptually differ from and are not comparable to the direct partial effects of immigration by experience estimated by the national skill-cell approach pioneered by Borjas (2003), or the direct partial effects of immigration by education estimated by studies exploiting spatial variation in the education- (or occupation-) specific immigration shock (e.g., Card 2001, 2009; Glitz 2012).

Specifications (7) and (8) are consistent with our experiment-because only the total but not the group-specific inflow of Czechs into the border region can be considered quasirandom. They have the added advantage that identification of $\beta_{g s}$ and $\delta_{g s}$ does not require the pre-allocation of immigrants to skill groups based on their observable characteristics, thus avoiding the problem of misclassification that arises when such observable characteristics are used to assign immigrants into skill groups in which they do not compete with natives. ${ }^{24}$

22. Moreover, whereas we measure the shock as the ratio of employed Czechs and employment in the base period, the literature typically measures the ratio of all incoming immigrants and the resident population in the base period (e.g., Card 2001, 2009; Boustan, Fishback, and Kantor 2010), or alternatively as the change in the immigrant share in the population (e.g., Altonji and Card 1991; Dustmann, Fabri, and Preston 2005; Dustmann, Frattini, and Preston 2013). The slope coefficient in the latter specifications will-if the employment rates of recent immigrants and natives differ-be different from -1 even if every immigrant who finds a job displaces a resident worker. In contrast, our specification measures the extent to which immigrants crowd out native employment irrespective of immigrants' willingness or ability to find a job.

23. Examples of studies identifying the total effects of immigration include Altonji and Card (1991), Dustmann, Fabbri, and Preston (2005), Saiz (2007), Boustan, Fishback, and Kantor (2010), Dustmann, Frattini, and Preston (2013), and Dustmann, Frattini, and Rosso (2015).

24. Dustmann and Preston (2012) illustrate that assigning immigrants to skill groups based on observed characteristics may lead to serious misclassification because immigrants often downgrade upon arrival. 


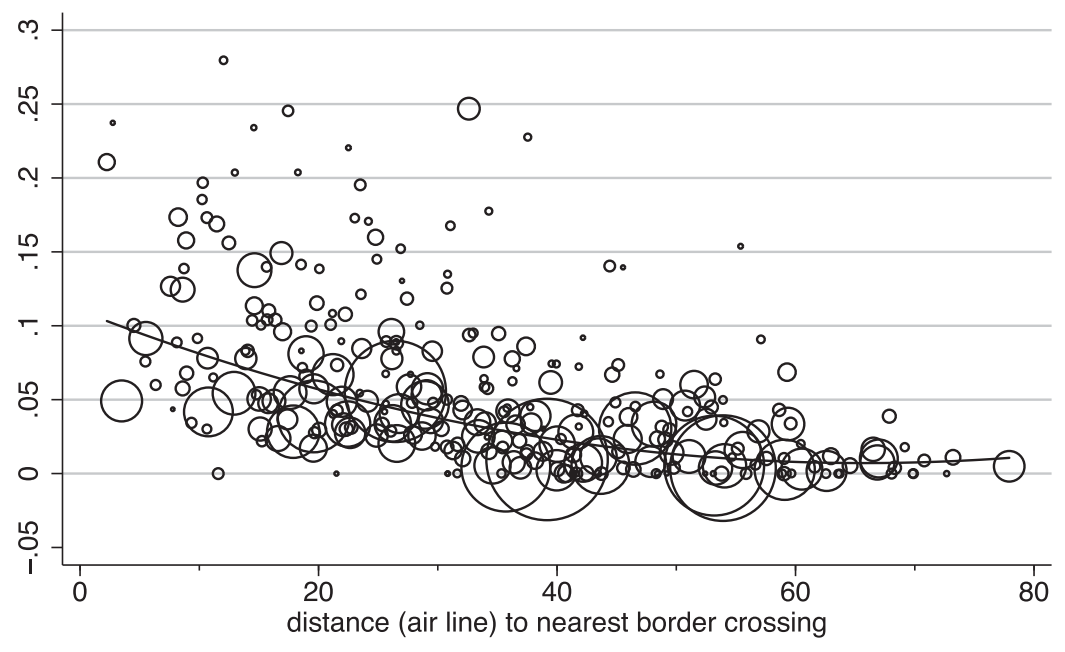

— Fitted values o share Czech 1992-1990

FIGURE III

Spatial Distribution of Czech Commuters in Border Region

The figure plots, for each municipality within the border region, the increase in the number of Czech workers as a share of employment in 1990 against the airline distance of the centroid of the municipality to the closest border crossing. The size of each circle is proportional to employment in 1990. Fitted values are from a regression on distance and distance squared. Data Source: German Social Security Records, border region, 1990 and 1992.

\section{IV.B. Estimation and Identification}

1. Exploiting Distance to Border. One option to estimate the effect of the immigration-induced labor supply shock on native workers' wages (equation [7]) and employment (equation [8]) would be to compare the entire border region eligible under the commuting policy with suitable control areas that were similar in observable characteristics but not eligible. However, the nature of the commuting experiment provides additional variation in the exposure of different areas to Czech inflows that can be usefully exploited: because Czech workers were forced to commute daily, increased traveling costs exposed municipalities close to the border more to the policy. In fact, as demonstrated in Section V.A, distance to the border was a key determinant of where Czech workers located within the border region, explaining $38.7 \%$ of the overall variation in the Czech employment share across municipalities (see also Figure III and Table III). We could 
TABLE III

First Stage: The Inflow of Czech Commuters and Distance to Border

\begin{tabular}{lcc}
\hline \hline & Border region only & $\begin{array}{c}\text { Including matched } \\
\text { control districts }\end{array}$ \\
\hline Distance $(\times 100)$ & -0.338 & -0.338 \\
Distance $(\times 100)$ squared & $(0.095)$ & $(0.092)$ \\
& 0.268 & 0.268 \\
Constant (border region) & $(0.113)$ & $(0.110)$ \\
& 0.115 & 0.114 \\
Constant (inland) & $(0.017)$ & $0.016)$ \\
No. municipalities & & 0.0011 \\
$R^{2}$ & 291 & $(0.0003)$ \\
$F$ & 0.387 & 1,550 \\
\hline \hline
\end{tabular}

Note. The table reports the coefficients from the first stage regression of the inflow of Czech workers into the municipality, measured as the increase in the number of Czech workers between 1990 and 1992 as a share of local employment in 1990, on airline distance and distance squared to the next border crossing. Regressions are estimated at the municipality level, weighted by local employment in 1990. In the first column, the sample is restricted to the border region. The second column additionally includes matched control districts, and distance and distance squared is interacted with an indicator variable equal to 1 if the municipality is part of the border region. Standard errors are clustered on the district level.

Data Source: German Social Security Records, border region and matched control districts, 1990 and 1992.

therefore also estimate equations (7) and (8) only for municipalities within the affected border region, using distance from the border region as an instrument. In our baseline specification, we combine the two approaches by pooling municipalities in the border region with unexposed control districts, thus exploiting variation in the employment share of Czechs within the border region in addition to using areas further inland as control units. To test the robustness of our findings we also report separate estimates based on the other two approaches, showing that all three approaches produce similar results (see Table V).

2. Assumptions. For distance to border to be a valid instrument, the following assumptions need to hold. First, and most important, in the absence of a Czech inflow, the evolution of subgroup-specific local wages and employment must be uncorrelated with distance from the border. We provide support for this assumption in Online Appendix D.I and Table O.I, by analyzing whether prior to the introduction of the commuting policies, municipalities in the border region closer to the border experienced differential trends in subgroup-specific outcomes from municipalities further away from the border. Reassuringly, the 
table shows that distance to border is, with one exception, uncorrelated with prepolicy trends in outcomes. Nevertheless, to make sure that our results are not driven by differential preexisting trends, we report results with and without controls for municipality-specific time trends. We further estimate placebo regressions in prepolicy periods and adopt an event study approach (for some outcomes) to illustrate graphically that distance to border affects native local wage and employment growth only after the inflow of Czech workers actually occurred.

In addition, for $\beta_{g s}$ and $\delta_{g s}$ in equations (7) and (8) to correspond to their theoretical counterparts in equations (4) and (5), "control" areas-that is, municipalities in matched inland districts and municipalities at the edge of the border region that received barely any Czech commuters-must not be affected by the Czech inflow into "treated" areas near the border. This condition would be violated if natives from the treated municipalities moved to control areas in response to the Czech inflow, thereby increasing employment and lowering wages in these areas. Because the labor supply shock to the border region was negligible in national terms, matched control areas that are not close to the border region are clearly unaffected by this shock. As a robustness check, we therefore compare the region very close to the CzechGerman border with a set of control districts located sufficiently far from the border, thereby discarding any variation in Czech inflow within the border region. We implement such a comparison using a synthetic control method (detailed in Online Appendix C) that compares a single treatment to a weighted average of available control units (see Abadie, Diamond, and Hainmueller 2010). This approach yields wage and employment effects that are similar to our baseline specification.

Finally, we need to rule out that the opening of the CzechWest German border directly affected areas close to the border, other than through the increased inflow of Czech workers into those areas. One channel through which the opening of the border could affect areas close to the border is increased trade between the border region and the Czech Republic or increased foreign direct investment (FDI) by firms in the border region in the Czech Republic. An alternative channel could be increased market access: areas close to the border may benefit from the opening of the border by occupying a more central position within Germany and Europe. We believe that both channels are unlikely, for two main reasons. First, in 1993 (the last year in our main empirical 
analysis), some trade restrictions between Germany and the Czech Republic were still in place and the trade volume between the two countries amounted only to around $1 \%$ of the German total. Similarly, throughout the mid-1990s, German FDI in the Czech Republic was relatively small in magnitude (around 1.9 billion dollars over the period 1990-1996) and concentrated in the capital Prague, rather than in areas close to the German border. In addition, as shown by Redding and Sturm (2008), gains from trade take a long time to materialize, whereas we focus on shortterm effects in the immediate aftermath of the border opening. Second, such shocks, if present, would be likely to affect the border region as a whole, but when we drop control districts further inland from our sample and exploit variation in Czech inflows within the border region only, our estimates are very similar.

3. Selecting Control Areas. The matching of control areas is based on variance-weighted differences in the employment share of the education groups, the employment share of foreign nationals, mean log wages, the share of right-censored wage observations, local employment levels, and the employment shares of four age groups in 1989 (the year before reunification and the fall of the Iron Curtain). We consider only West German districts of similar urban density, and we do not match on preexisting time trends. The 24 matched control districts (corresponding to 1,259 control municipalities) depicted in Figure I are much more similar to border districts than other West German districts (see column (3) of Table I). ${ }^{25}$ Our baseline specification thus refers to 1,550 municipalities (291 in the border region and 1,259 control municipalities). The exact number varies slightly across subgroups and years, as there are some small municipalities that do not employ workers of a specific type or in a specific year.

In contrast, when using the synthetic control approach, which discards all variation across municipalities within the border region, we match similarly on the education, foreign and age shares, but also on outcome variables from 1986 to 1989 (cf. Abadie, Diamond, and Hainmueller 2010). In these estimates, therefore, we explicitly match on preexisting time trends (see Online Appendix $\mathrm{C}$ for details).

25. Three out of the 24 matched control districts are located next to the border region. Our findings are very similar if we exclude these neighboring control districts from the sample. 
4. Timing and Placebo Tests. When estimating equations (7) and (8), we adopt a flexible specification that allows us to assess how quickly local wages and employment adjust in response to the labor supply shock. Although the regressor $\Delta C_{j}^{92-90}$ is always defined as the inflow of Czech workers into area $j$ between 1990 and 1992 as a share of local employment, we estimate annual regressions of wage or employment changes between the years $t$ and $t-1$ on $\Delta C_{j}^{92-90}$, instrumented with distance to border. To obtain the overall impact of the labor supply shock over longer periods, we then sum the respective coefficient estimates for $t=1991$ to $t=$ $1993 .{ }^{26}$ Running yearly rather than long difference regressions is not only informative about the timing of adjustment but allows us to address potential selectivity bias in wage estimates, as the employment response to a labor supply shock may differ across the wage distribution (see Bratsberg and Raaum 2012 and Llull 2013, for a discussion). To deal with selection, we restrict in the wage analysis the sample to individuals who are employed in the municipality in both $t$ and $t$-1, thus keeping the composition of workers constant over the two time periods. As illustrated below, we find that if instead longer differences are estimated on data that discard longitudinal worker information, selective employment response does indeed lead to underestimation of the wage effects.

We also estimate equations (7) and (8) for the years prior to 1990, when the later inflow of Czech nationals should have no impact on native employment changes. Formulating the hypotheses $H_{0}: \beta_{g s}=0$ and $H_{0}: \delta_{g s}=0$ for $t \leqslant 1990$ provides a placebo setup against which to probe the identifying assumption that areas located close to the border experienced the same time trends prior to 1990 as areas located further away. Since we did not match on preexisting trends when selecting control districts, these estimates provide a valid falsification test. ${ }^{27}$

Since our estimation strategy proceeds in multiple stages, which makes the computation of analytical standard errors complicated, we bootstrap standard errors using the wild-bootstrap

26. We implement the IV estimator in two steps: a first stage estimation at the municipality level, regressing $\Delta C_{j}^{92-90}$ on distance to border and its square and weighting each observation by total employment in the municipality in 1990; and a second stage regression of subgroup-specific native employment and wages in the municipality on the predicted inflow of Czechs, $\Delta \hat{C}_{j}^{92-90}$, with each observation weighted by subgroup-specific employment in t- 1 .

27. Angrist and Krueger (1999) implement a similar test, illustrating that the estimated effect of the Mariel Boatlift on the Miami labor market is sensitive to differences in trends between treatment and control units. 
procedure and 500 repetitions (see Cameron, Gelbach, and Miller 2008). While our analysis is performed at the municipality level, we cluster standard errors at the district level. For our main outcomes of aggregate and skill-specific local wage and employment effects of natives, we additionally report standard errors based on the Spatial Heteroscedasticity and Autocorrelation Consistent (SHAC) variance estimator proposed by Conley (1999) and adopted by for example Kline and Moretti (2014), which allows for correlation between areas that are geographically close but belong to different administrative units (see column (5) in Table V). ${ }^{28}$ The standard errors are very similar to our baseline bootstrapped standard errors which allow for clustering at the district level.

\section{REsults}

\section{V.A. First Stage: Distance to Border and Location of Czechs}

In Figure III, we plot Czech employment growth from 1990 to $1992, \Delta C_{j}^{92-90}$, in municipalities within the border region against the municipality's distance to the closest border crossing, $Z_{j}$, weighting municipalities according to 1990 employment levels. As the figure illustrates, distance to border is indeed a key determinant of where Czech nationals located within the border region: municipalities next to the border received the largest inflow of Czech workers, corresponding on average to almost $10 \%$ of employment in 1990. Municipalities located more than 50 kilometers away from the border, in contrast, experienced hardly any inflow.

We report the corresponding regression results (the first stage), approximating the relationship between the inflow of Czech nationals and distance to border as a quadratic function, in Table III, reporting results for the border region only in column (2) and for the estimation sample including matched control districts in column (3). The coefficients on distance and distance squared are jointly highly significant $(\mathrm{F}=42.58)$ and together explain $38.7 \%$ of the variation in the Czech employment share

28. There are various difficulties in applying this procedure to our context since, in contrast to Kline and Moretti (2014), our estimation strategy proceeds in multiple stages. We have implemented the SHAC standard errors in our long difference specification, ignoring uncertainty from the first stage. Additional robustness checks show that ignoring the uncertainty in the first stage has little impact on the standard errors (see Online Appendix D.III and Table O.III). 
across municipalities within the eligible border region or $54.4 \%$ of the variation across border and matched control municipalities. ${ }^{29}$

\section{V.B. The Impact of Czech Inflows on Native Wages and Employment}

1. Aggregate Wage and Employment Effects. Figure IV provides a first visual assessment of the Czech inflow's effect on the local wages and employment of all native workers in the municipality. These figures are based on our estimations of equations (7) and (8), which regress municipality-level changes in native wages or employment between two consecutive years on the Czech inflow between 1990 and 1992 (except for 1991, which is based on the 1990-1991 inflow) instrumented by the municipality's distance to the border. ${ }^{30}$ We then plot the cumulative effects relative to 1990 by summing the estimated slope coefficients backward and forward. The outcomes thus represent the cumulative wage (employment) effects of the Czech inflow between 1990 and 1992 for each year between 1986 and 1995. We display the corresponding cumulative post-policy regression coefficient in 1993 in row (i) of Table IV (Panel A).

As the figures show, prior to 1990, the estimated coefficients for both employment and wages are small and statistically not significantly different from zero, meaning that distance to border does not help to predict local employment and wage trajectories in the prepolicy period (see also Online Appendix Table O.I). We thus cannot reject the falsification test described in Section IV.B. After the policy comes into effect in 1990, however, local wagesand in particular local employment of native workers-drop significantly. Whereas wages respond immediately, the employment effect builds up and employment continues to decline from 1992 to 1993, although the employment share of Czech workers reaches its peak in 1992. By 1993, a 1 percentage point increase in the

29. We have estimated a variety of alternative first stages based on different functional form assumptions (i.e., a third order polynomial and a spline function in distance to border) and different distance measures (driving distance and driving time). These alternative specifications yield very similar first stage and 2SLS estimates (see Online Appendix D.II and Table O.II).

30. In Online Appendix D.VII and Table O.V we report separate estimates by gender, while in Online Appendix D.VIII and Table O.VI we instead consider specifications that include the skill-specific change in the employment share of Czech workers. As also discussed in Section IV.A, such specifications identify only the relative effects of immigration. 

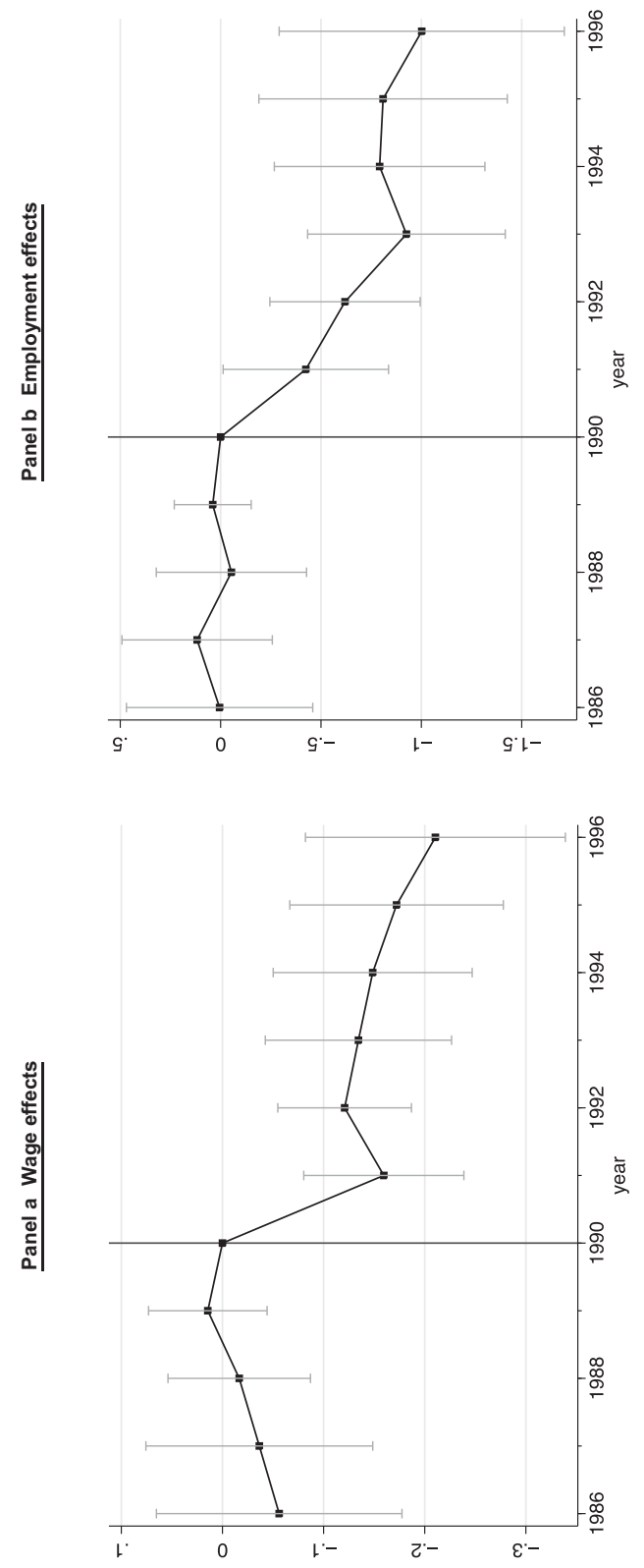

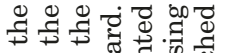
to जू \&

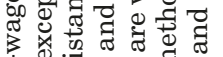

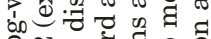

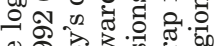

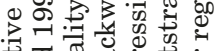
牙 요유 o 9 . 管

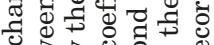

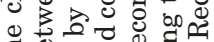

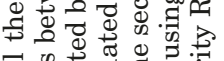
ब

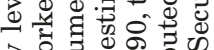
店它 ब. 원.? 일 द्व 约

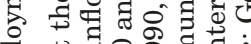
$\geq$ 范 폴 포

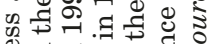
동 요 议

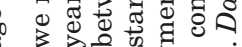
3 o n

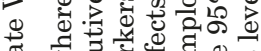
B क人 4 उ สี E

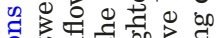
.

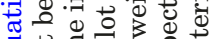

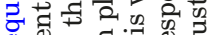

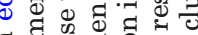

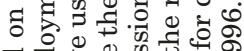

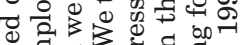
oै द्व

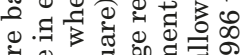
के थ द्व

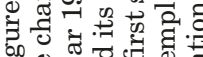

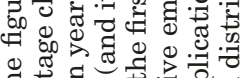

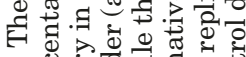
d 
Wage ANd Employment Baseline Estimates By Skill, 1990-1993

\begin{tabular}{cccc}
\hline \hline & & Wages & Employment \\
\hline $\begin{array}{llc}\text { Panel A: All } \\
\text { (i) }\end{array}$ & & & \\
& & & \\
(ii) & & -0.134 & -0.926 \\
& & $(0.047)$ & $(0.251)$ \\
Panel B: Unskilled & -0.058 & -0.263 \\
(i) & 2SLS & $(0.038)$ & $(0.184)$ \\
& & & \\
(ii) & OLS & -0.202 & -1.371 \\
& & $(0.048)$ & $(0.395)$ \\
Panel C: Skilled & -0.094 & -0.789 \\
(i) & & $(0.041)$ & $(0.215)$ \\
& 2SLS & & \\
(ii) & OLS & -0.106 & -0.501 \\
& & $(0.051)$ & $(0.214)$ \\
& No. municipalities & -0.054 & 0.049 \\
& & $(0.025)$ & $(0.196)$ \\
\hline \hline
\end{tabular}

Note. The table reports 2SLS (rows (i)) and OLS (rows (ii)) estimates for the impact of the inflow of Czech commuters into the municipality, measured as the increase in the number of Czech workers between 1990 and 1992 as of employment in 1990, on native local wage and employment growth in the aggregate (Panel a) and for unskilled and skilled natives (Panels b and c). In rows (i), the inflow of Czech workers is instrumented with a quadratic in the municipality's airline distance to the nearest border crossing. Regressions are estimated at the yearly level, across up to $\mathrm{N}=1,550$ municipalities, and coefficients are added up to obtain cumulative effects. To make sure that the wage effects are not underestimated because of worker selection, the yearly wage growth regressions are restricted to workers who remain employed in the district between two consecutive years. While the first stage regression is weighted by total native employment in the municipality in 1990, the second stage regression is weighted by group-specific native employment in the respective base year. Standard errors are bootstrapped, using 500 replications, allowing for clustering on the district level.

Data Source: German Social Security Records, border region and matched control districts, 1990 to 1993.

inflow of Czech workers relative to employment in the baseline has led to about a $0.13 \%$ decrease in native wages, a $0.93 \%$ decrease in native local employment, and a 0.07 (1-0.93) percent increase in total (including Czech) local employment. Putting the wage response into perspective, the real wage growth over the period considered of workers employed in the two consecutive periods was about 3\% per year, meaning that the negative wage effects do not necessarily imply a decline in natives' real wages.

Interpreted within the simple model laid out in Section II, these negative overall wage and employment effects suggest that at least in the short run, the local supply of capital is not fully elastic. ${ }^{31}$ The large employment response, coupled with a smaller

31. We report evidence on firm entry in the tradable and nontradable sectors in Online Appendix D.VI and Table O.IV. 
wage response, could either be driven by a high local labor supply elasticity or by wages being partially downward rigid in the short run, or both. Our estimates further imply a wage elasticity $(\varphi=$ $-\frac{\alpha \lambda}{1-\alpha+\lambda}$ in our model) of $0.54\left(\frac{0.07}{0.13}\right)$, which is well within the range of existing estimates ranging from 0.15 to 0.75 (e.g., Hamermesh 1993; Lichter, Peichl, and Siegloch 2015).

2. Wage and Employment Effects by Skill Group. According to Table II, a higher fraction of Czech commuters was unskilled relative to natives. We would therefore expect the overall inflow of Czechs to depress local wages and employment of native unskilled workers by more than those of native skilled workers, unless the two groups differ in their wage rigidity or supply elasticity; see equations (2), (4) and (5). We indeed find that both the wages and employment of native unskilled workers do decline relative to native skilled workers (see Table IV, Panels b and c). Over the 1990-1993 period, a 1 percentage point increase in the employment share of Czech workers decreases the local wages and employment of unskilled natives by 0.20 and $1.37 \%$, respectively, but of skilled natives by only 0.11 and $0.50 \%$. Rows (ii) of Table IV reports simple OLS estimates that do not instrument the share of Czech workers by distance to the border. Here, the estimated wage and employment effects are smaller than the IV estimates, particularly for skilled workers. This outcome is to be expected if Czech workers predominantly entered municipalities experiencing higher employment and wage growth.

As an alternative measure for skill, we use individuals' occupation (see Figure V). Specifically, we estimate our baseline specification separately for nine 1-digit occupations and plot the resulting 2SLS cumulative (1990 to 1993) wage (Panel a) and employment (Panel b) coefficients in an occupation against the occupation's exposure to the labor supply shock, measured as the employment share of Czech commuters in the occupation in 1992 divided by the average share. The figure clearly demonstrates that local wages and employment of natives declined more in occupations with a larger exposure to Czech workers. Similarly, employment of native workers declines more strongly in industries that experienced a larger inflow of Czech workers (see Online Appendix D.V and Figure O.II). 

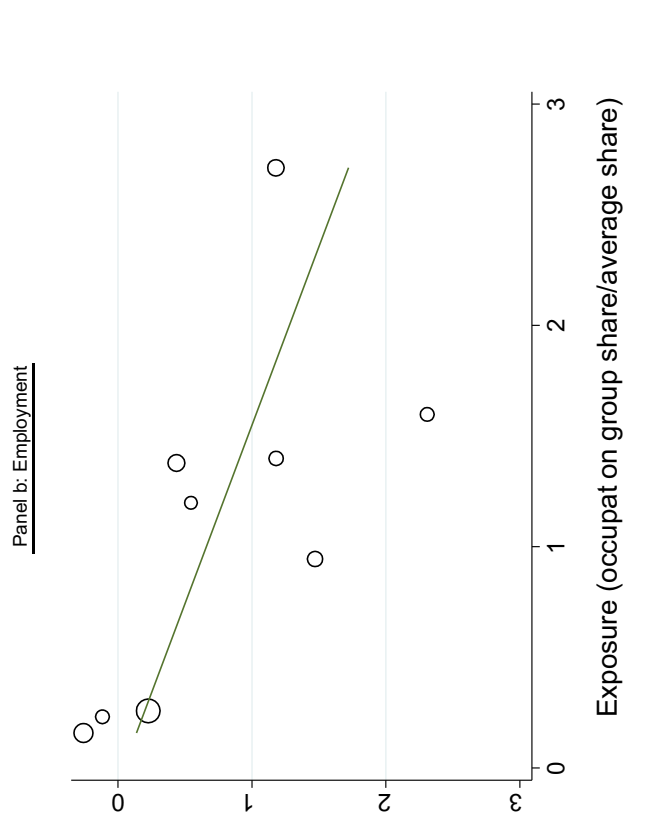

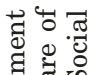
을 चี 형 ํㅐㄹ वृ कृ ธ. 응 క 局 㝴击 类 웡 政 웡 专 है की : 丞 क

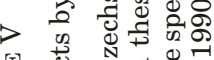

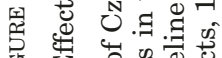
단

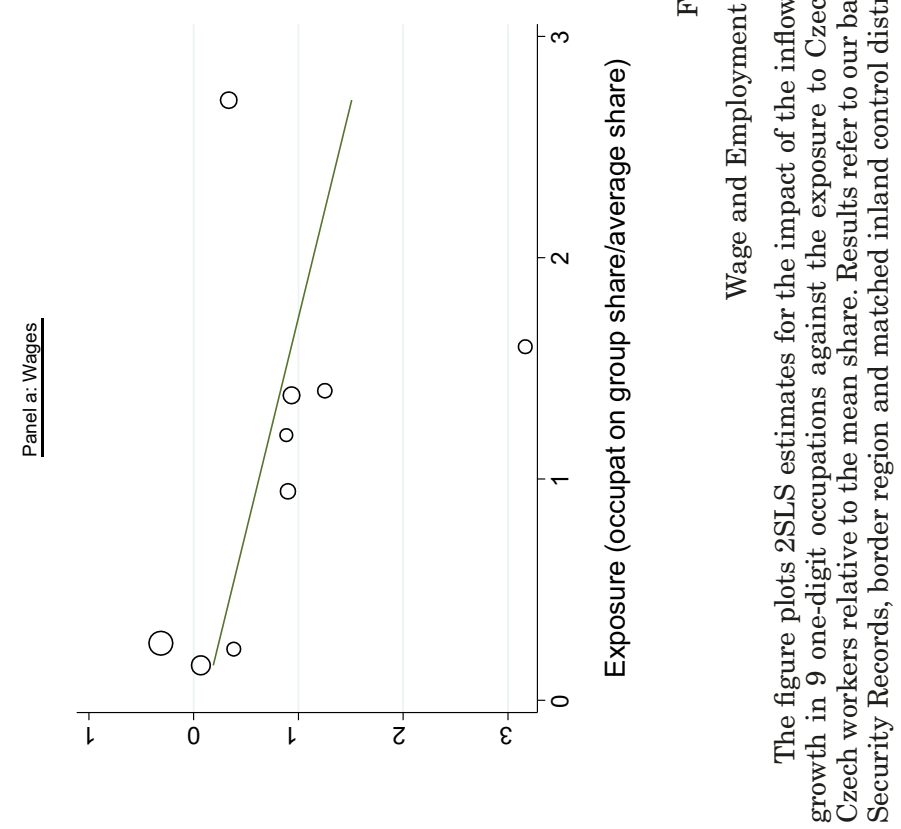


TABLE V

RoBustNess CHECKS

\begin{tabular}{|c|c|c|c|c|c|}
\hline & Baseline & $\begin{array}{c}\text { (2) } \\
\text { Trend- } \\
\text { adjusted }\end{array}$ & $\begin{array}{l}(3) \\
\text { Border } \\
\text { region } \\
\text { only }\end{array}$ & $\begin{array}{l}\text { (4) } \\
\text { Inner border } \\
\text { region vs. } \\
\text { inland }\end{array}$ & $\begin{array}{c}\text { (5) } \\
\text { Long } \\
\text { difference, } \\
\text { SHAC s.e. }\end{array}$ \\
\hline \multicolumn{6}{|l|}{ Panel A: Wage effects } \\
\hline All & $\begin{array}{c}-0.134 \\
(0.047)\end{array}$ & $\begin{array}{r}-0.209 \\
(0.056)\end{array}$ & $\begin{array}{r}-0.134 \\
(0.096)\end{array}$ & $\begin{array}{r}-0.142 \\
(0.050)\end{array}$ & $\begin{array}{c}0.002 \\
(0.053)\end{array}$ \\
\hline Unskilled & $\begin{array}{c}-0.202 \\
(0.048)\end{array}$ & $\begin{array}{c}-0.282 \\
(0.068)\end{array}$ & $\begin{array}{r}-0.303 \\
(0.105)\end{array}$ & $\begin{array}{c}-0.205 \\
(0.051)\end{array}$ & $\begin{array}{r}-0.057 \\
(0.080)\end{array}$ \\
\hline Skilled & $\begin{array}{c}-0.106 \\
(0.051)\end{array}$ & $\begin{array}{c}-0.190 \\
(0.060)\end{array}$ & $\begin{array}{c}-0.093 \\
(0.098)\end{array}$ & $\begin{array}{c}-0.114 \\
(0.054)\end{array}$ & $\begin{array}{c}-0.052 \\
(0.050)\end{array}$ \\
\hline \multicolumn{6}{|c|}{ Panel B: Employment effects } \\
\hline All & $\begin{array}{r}-0.926 \\
(0.251)\end{array}$ & $\begin{array}{c}-0.927 \\
(0.311)\end{array}$ & $\begin{array}{r}-0.952 \\
(0.456)\end{array}$ & $\begin{array}{c}-0.897 \\
(0.275)\end{array}$ & $\begin{array}{r}-0.930 \\
(0.243)\end{array}$ \\
\hline Unskilled & $\begin{array}{c}-1.371 \\
(0.395)\end{array}$ & $\begin{array}{c}-1.417 \\
(0.411)\end{array}$ & $\begin{array}{r}-1.036 \\
(0.522)\end{array}$ & $\begin{array}{c}-1.368 \\
(0.382)\end{array}$ & $\begin{array}{c}-1.203 \\
(0.271)\end{array}$ \\
\hline Skilled & $\begin{array}{c}-0.501 \\
(0.214)\end{array}$ & $\begin{array}{c}-0.866 \\
(0.313)\end{array}$ & $\begin{array}{c}-0.586 \\
(0.450)\end{array}$ & $\begin{array}{c}-0.507 \\
(0.236)\end{array}$ & $\begin{array}{c}-0.522 \\
(0.230)\end{array}$ \\
\hline No. municipalities & 1,550 & 1,550 & 291 & 1,405 & 1,550 \\
\hline
\end{tabular}

Note. The table presents coefficient estimates from various robustness tests. Column (1) reports our baseline estimates (see Table IV, rows (i)). Column (2) allows for linear municipality-specific time trends in pooled regressions, in which the pretreatment observations in 1987-1989 identify municipality-specific differences in trend. Column (3) drops matched control districts from the sample and uses variation in the inflow of Czechs across municipalities within the border region only. Column (4) compares the highly affected Eastern ("inner") part of the border region to unaffected matched control districts. In column (5), we report estimates for which we take long differences (between 1990 and 1993) and average log wages over all workers who are in employment in either of the two years, rather than over workers who remain employed in two consecutive years, as in our baseline specification in column (1). In columns (1) to (4), standard errors are bootstrapped, using 500 replications, allowing for clustering on the district level. Column (5) displays instead standard error estimates based upon spatial HAC technique of Conley (1999), using a uniform kernel and bandwidth of 100 kilometers.

Data Source: German Social Security Records, border region and matched control districts, 1987 to 1993.

\section{V.C. Robustness Checks}

1. Common Time Trend and Sample Selection. The findings in Table IV are robust to a number of specification checks, reported in Table $\mathrm{V}$ and using the 2SLS estimates from Table IV (row (i)), as a reference point. In column (2), we account for possible municipality-specific time trends, identified based on 19871989 data, and report trend-adjusted estimates. The employment estimates are similar to those reported in column (1), while the wage estimates are larger in magnitude. In column (3), we drop all control districts and compare only differentially exposed areas within the border region, whereas in column (4) we compare the region very close to the Czech-German border-which we refer to from now on as the "inner border region" and which, because 
of shorter distance to the border, received the vast majority of Czech inflows-with unaffected control areas. ${ }^{32}$ In both cases, the results are very similar to those for our baseline estimates, indicating that our findings are not dependent on the particular matching of control districts, and providing indirect support for our identifying assumption (discussed in Section IV.B).

2. Worker Selection. Column (5) of Table V reports the results of estimating equations (7) and (8) in long differences; that is, regressing local wage and employment growth between 1990 and 1993 on Czech inflows between 1990 and 1992 rather than estimating annual regressions and summing the coefficients as in column (1). In these calculations, as is common in studies using repeated cross-sectional data, (log) wages are averaged over all workers who are employed in any of the two years, 1990 and 1993 , rather than over workers who remain employed in the district in two consecutive years as in our baseline specification. As expected, the employment effect estimates are barely affected and remain very similar to those in the first column. ${ }^{33}$

These calculations do, however, highlight the importance of how wages are measured. The results of the long difference estimations point to no significant wage effects of the Czech inflow for either skill group. This finding suggests that the workforce composition changes as a result of the labor supply shock, with low-wage workers more likely to leave or not enter the workforce in response to immigration. Hence, a simple comparison of average wages before and after the migration-induced supply shock underestimates the wage effect on the remaining workers, meaning that if immigration leads to selective employment effects, estimations based on repeated cross sections some years apart may underestimate, or even fail to detect, adverse wage effects.

32. We split municipalities within the border region according to their fitted values from the first stage regression. The inner border region is comprised of 145 municipalities in which the predicted inflow of Czech was above the median, averaging to about $5.8 \%$ of total employment.

33. The small difference arises for two reasons: First, the baseline specification weights the annual regressions by group-specific employment in $t-1$, which changes slightly from year to year, while the long difference regression references only 1990. Second, the sum of annual employment growth rates $\left(\frac{L_{j t}^{N}-L_{j t-1}^{N}}{L_{j t-1}^{N}}\right)$ does not correspond exactly to the employment growth rate over three time periods $\left(\frac{L_{j t}^{N}-L_{j t-3}^{N}}{L_{j t-3}^{N}}\right)$. 
3. Synthetic Control Approach. An alternative estimation strategy, the synthetic control approach, discards the variation in municipalities' exposure to Czech commuters induced by distance to the Czech-German border, and instead compares wages and employment of the entire (inner) border region with those in the matched control districts. It thus internalizes all employment movements across municipalities within the border region. To obtain sharper results, we compare the evolution of aggregate native employment and wages in the highly exposed inner border region (treatment unit) with that in unexposed control districts (synthetic control units). Figure VI displays the evolution of the native wage (Panel a) and employment (Panel b) gaps between the inner border region and its synthetic control (bold line). As the figure shows, whereas both native wages and employment unfold in almost the same way in the treatment and control units prior to the policy (recalling that in contrast to Figure IV, we are now explicitly matching on trends), in 1991 a gap begins to emerge in the treatment area relative to the control areas. To assess the statistical significance of this divergence, the figure also displays permutation tests in which we apply the synthetic control method to every potential control in our sample (as in Abadie, Diamond, and Hainmueller 2010). The results show that the employment but not the wage gap is exceptionally large in the treated inner border region compared to placebo districts, indicating statistical significance of the employment but not the wage gap. It is not surprising that outcomes from the synthetic control approach are more noisily estimated than our baseline estimates, as this approach discards any variation in the inflow of Czech workers within the inner border region.

To compare these outcomes with our estimates for the impact of the inflow of Czech workers on native local wage and employment growth, we must scale the wage and employment gaps $(-0.007$ and -0.079 by 1993$)$ by the share of Czech workers that entered the treatment region $(5.8 \%)$. The results, -0.12 for wages, and -1.36 for employment, are roughly in the same ballpark as our baseline coefficients of -0.13 and -0.93 in row (i) of Table IV (Panel a). Estimates by skill group, reported in Online Appendix D.IV and Figure O.I, are likewise similar. Hence, the inflow of Czech workers into the inner border area led to an overall decline in native employment in that region and not merely to employment shifts across municipalities within the region. 


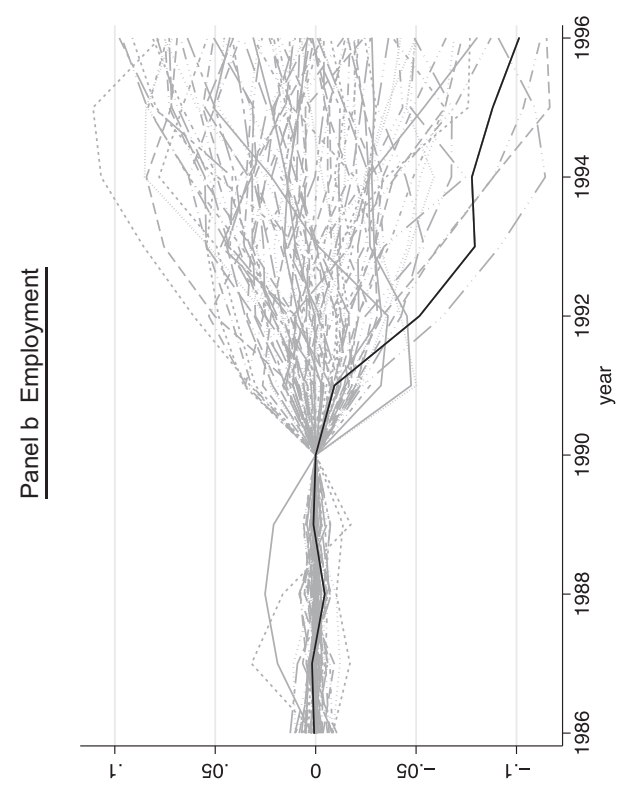

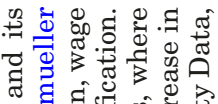

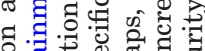
항

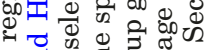
on 娄 政设 屯ี ్ㅐ 向嵌

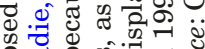
की 冈.

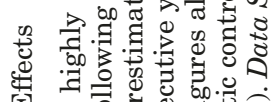
o 0 焉

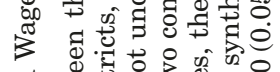

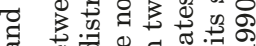
o 0 व

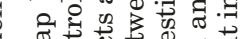

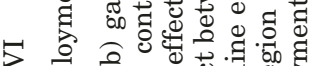
国 氖

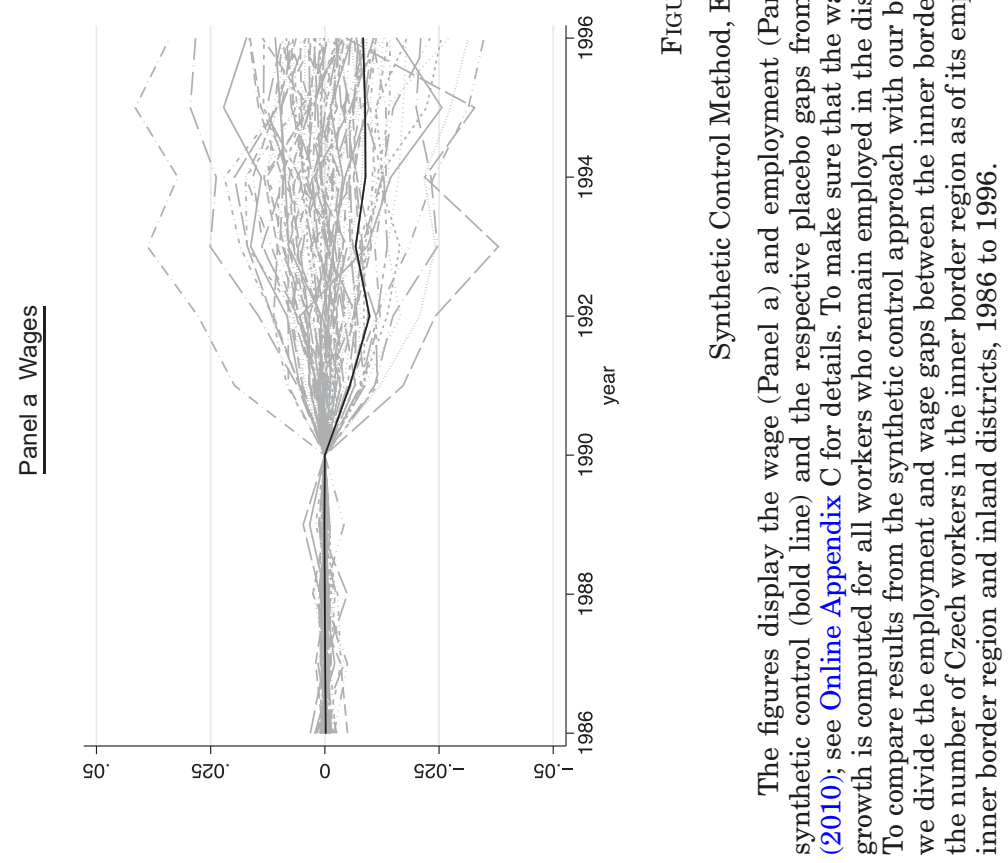


TABLE VI

Employment and Wage Effects by Skill ANd Age Groups

\begin{tabular}{|c|c|c|c|c|}
\hline & \multirow{2}{*}{\multicolumn{2}{|c|}{$\begin{array}{l}(1) \\
\text { Unadjusted }\end{array}$}} & \multirow{2}{*}{\multicolumn{2}{|c|}{$\begin{array}{l}\text { (3) } \\
\text { Trend-adjusted }\end{array}$}} \\
\hline & & & & \\
\hline & Wages & Employment & Wages & Employment \\
\hline \multicolumn{5}{|l|}{ Panel A: All } \\
\hline Below 30 & -0.316 & -0.832 & -0.305 & -0.604 \\
\hline (Share Czechs: 0.031) & $(0.086)$ & $(0.317)$ & $(0.079)$ & $(0.373)$ \\
\hline 30 to 49 & -0.100 & -0.534 & -0.147 & -0.964 \\
\hline (Share Czechs: 0.040) & $(0.050)$ & $(0.238)$ & $(0.058)$ & $(0.338)$ \\
\hline 50 and above & -0.068 & -1.945 & -0.172 & -1.428 \\
\hline (Share Czechs: 0.007) & $(0.046)$ & $(0.340)$ & $(0.055)$ & $(0.394)$ \\
\hline \multicolumn{5}{|l|}{ Panel B: Unskilled } \\
\hline Below 30 & -0.558 & -2.262 & -0.441 & -1.601 \\
\hline (Share Czechs: 0.112) & $(0.107)$ & $(0.585)$ & $(0.103)$ & $(0.549)$ \\
\hline 30 to 49 & -0.179 & -0.704 & -0.237 & -1.428 \\
\hline (Share Czechs: 0.107) & $(0.064)$ & $(0.428)$ & $(0.078)$ & $(0.501)$ \\
\hline 50 and above & -0.097 & -1.364 & -0.194 & -1.324 \\
\hline (Share Czechs: 0.011) & $(0.053)$ & $(0.342)$ & $(0.080)$ & $(0.470)$ \\
\hline \multicolumn{5}{|l|}{ Panel C: Skilled } \\
\hline Below 30 & -0.276 & -0.283 & -0.281 & -0.457 \\
\hline (Share Czechs: 0.017) & $(0.092)$ & $(0.319)$ & $(0.081)$ & $(0.378)$ \\
\hline 30 to 49 & -0.090 & -0.191 & -0.142 & -1.012 \\
\hline (Share Czechs: 0.025) & $(0.058)$ & $(0.197)$ & $(0.063)$ & $(0.329)$ \\
\hline 50 and above & -0.066 & -1.636 & -0.158 & -1.337 \\
\hline (Share Czechs: 0.005) & $(0.053)$ & $(0.275)$ & $(0.061)$ & $(0.383)$ \\
\hline No. municipalities & 1,550 & 1,550 & 1,550 & 1,550 \\
\hline
\end{tabular}

Note. The table reports 2SLS estimates for the cumulative impact, between 1990 and 1993, of the inflow of Czech commuters between 1990 and 1992 on local wage and employment growth of natives by age (Panel a) and by age and skill (Panels b and c). Columns (1) and (2) report unadjusted estimates from regressions estimated at the yearly level, where coefficients are added up to obtain cumulative effects. Columns (3) and (4) report trend-adjusted estimates, obtained from a pooled regression over the years 1987 to 1993, in which pretreatment observations in 1987-1989 identify differences in the linear municipality-specific time trend. While the first stage regression is weighted by total native employment in the municipality in 1990, the second stage regression is weighted by group-specific native employment in the respective base year. Standard errors are bootstrapped, using 500 replications, allowing for clustering at the district level.

Data Source: German Social Security Records, border region and matched inland control districts, 1987 to 1993.

\section{V.D. Age Group-Specific Responses}

In Table VI, we provide a more detailed analysis by investigating whether the Czech inflow affects labor market outcomes differently for younger $(<30)$ and older $(\geqslant 50)$ natives. The estimates refer to our baseline specification, which links the overall inflow of Czech workers to skill- and age-specific wage and employment growth (equations [7] and [8]) and captures the cumulative effects up until 1993. We report two types of estimates: those 
that are not trend adjusted (columns (1), (2)) and those that are (columns (3), (4)).

The findings point toward perverse effects across age groups, in particular for skilled workers. As Table I shows, in comparison to natives, Czech workers were more concentrated in the medium age range (30-49) than among young and older workers. Thus, according to standard immigration models, which restrict labor supply elasticities (or the degree of wage rigidity) to be the same across age groups (and may allow for imperfect substitutions), both employment and wages should decline the most for the middle-aged within each skill group. The estimates in Table VI, however, suggest that among skilled workers, young workers below 30 suffer the largest wage loss of all three age groups, whereas older workers aged 50 and above suffer the largest employment losses. The pattern is similar among unskilled workers.

Our model provides two complementary explanations for this pattern. First, older workers may be more elastic in their labor supply than younger workers. This is plausible, as older workers may have easier access to social security and unemployment benefits than young workers-who in turn may be willing to accept wage cuts at the beginning of their career to avoid scarring. Second, wages may be more downward rigid for older than for younger workers as younger workers are typically on a steep wage growth path whereas wages of older workers no longer grow (recall that our wage analysis is restricted to workers who are employed in two consecutive time periods). Thus, real wage cuts may be particularly visible and difficult to implement for older workers, while for younger workers they imply lower growth than they otherwise would have.

\section{V.E. Margins of Adjustment}

1. Inflows versus Outflows. The overall employment effect reported above can be decomposed into workers who leave employment in a particular area (outflows) and workers who do not enter employment but would have done so in the absence of the labor supply shock (inflows), that is, $\frac{L_{g t, j}^{N}-L_{g t-1, j}^{N}}{L_{g t-1, j}^{N}}=\frac{\text { Inflow } w_{g, j}^{N}}{L_{g t-1, j}^{N}}-\frac{\text { Outflow } w_{g, j}^{N}}{L_{g t-1, j}^{N}}$, where $\operatorname{Inflow}_{g}^{N}$ is the number of natives employed in area $j$ in year $t$ but not in year $t$-1, while Outflow $w_{g}^{N}$ captures those natives who were employed in $t$ - 1 but not in $t$. In Figure VII we report estimates of the labor supply shock-induced impact on the inflow (Panel a) 
and outflow (Panel b) rates using the same regressions as in Figure IV, with the overall inflow and outflow rates as the dependent variable. Unlike Figure IV, however, Figure VII represents yearly rather than cumulative responses. The results indicate that overall yearly employment effects are driven primarily by a reduction in inflows and to a far lesser extent by an increase in outflows. Moreover, whereas the inflow response is immediate, the outflows response is delayed and begins increasing only in 1991, one year after the policy came into effect. This immediate response to inflows helps explain why native employment levels seem to react so rapidly to local shocks.

Table VII provides detailed estimates using column (1) as the reference for employment effects in the aggregate (Panel a) and for different skill groups (Panel b) and age groups (Panel c). ${ }^{34}$ Columns (2) and (3) show the reduction in inflows and increase in outflows, respectively, each of which makes up roughly $17 \%$ of average employment over the 1985-1989 prepolicy period. All table entries refer to the overall effect by 1993, and, as before, are obtained by summing the coefficients from the annual regressions. As Figure VII and the table entries indicate, inflows are far more important than outflows for explaining the total employment response in all skill and age groups, accounting for at least $87 \%$ of the overall reduction in employment. The outflow margin is largest for older workers, for whom outflows make up $28 \%$ of the overall employment effect.

This finding puts a new spin on the usual interpretation of employment responses to labor supply shocks. In particular, rather than implying that native workers lose their jobs as Czechs enter the local labor market, the large employment response is induced by workers not employed in the affected area (but possibly in other areas) at the time of the policy no longer being hired. One explanation for why the local employment decline is almost entirely absorbed by reduced hiring as opposed to increased separations is that this group of "outsiders" is particularly elastic in their

34. Because inflow and outflow rates tend to be smaller in municipalities close to the border, the overall employment estimates reported in Table VII, column (1), are trend adjusted and differ slightly from our baseline estimates in Table IV. Since a large NATO cold war military exercise (REFORGER 88) in the border region in 1988 coincided with an unusually large outflow of workers from the 1987-1988 social security records who returned in 1989, we use only 1989 and 1990 to account for municipality-specific preexisting time trends rather than the 1987-1989 period used in Table V, column (2), and Table VI, columns (3) and (4). 


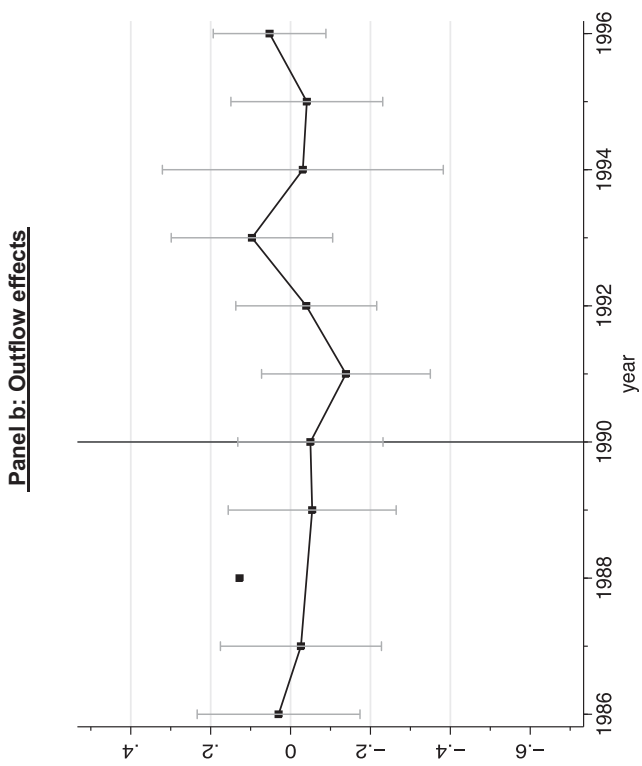

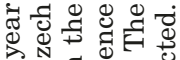
원.

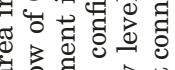

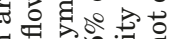
ㅖ.9융용 ฐ 울 官 政

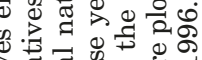
跣券

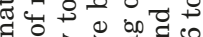
욜. 경 व

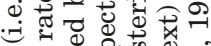
o 0 要

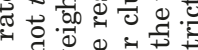

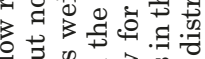

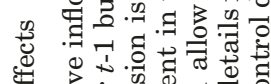
品要 3 đ

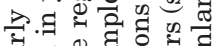

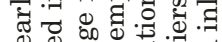
궁 国

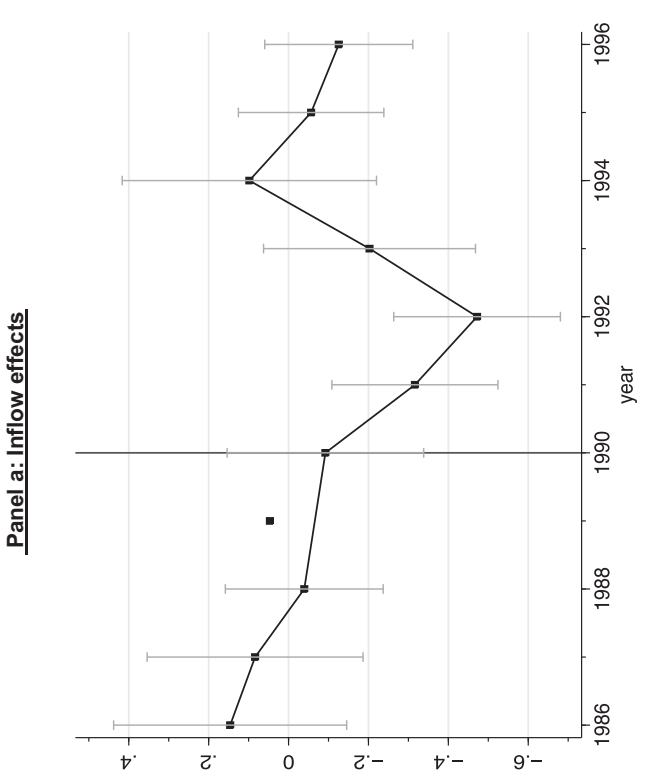

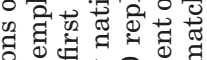
을 क 눈 जी

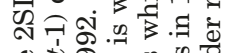
市学

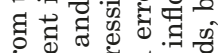
4 t50 क 눈

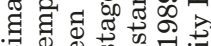
\% 空造 过

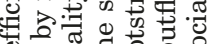
\& 늘: 영 कै 0 . 空吉

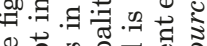

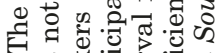

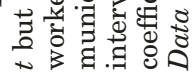




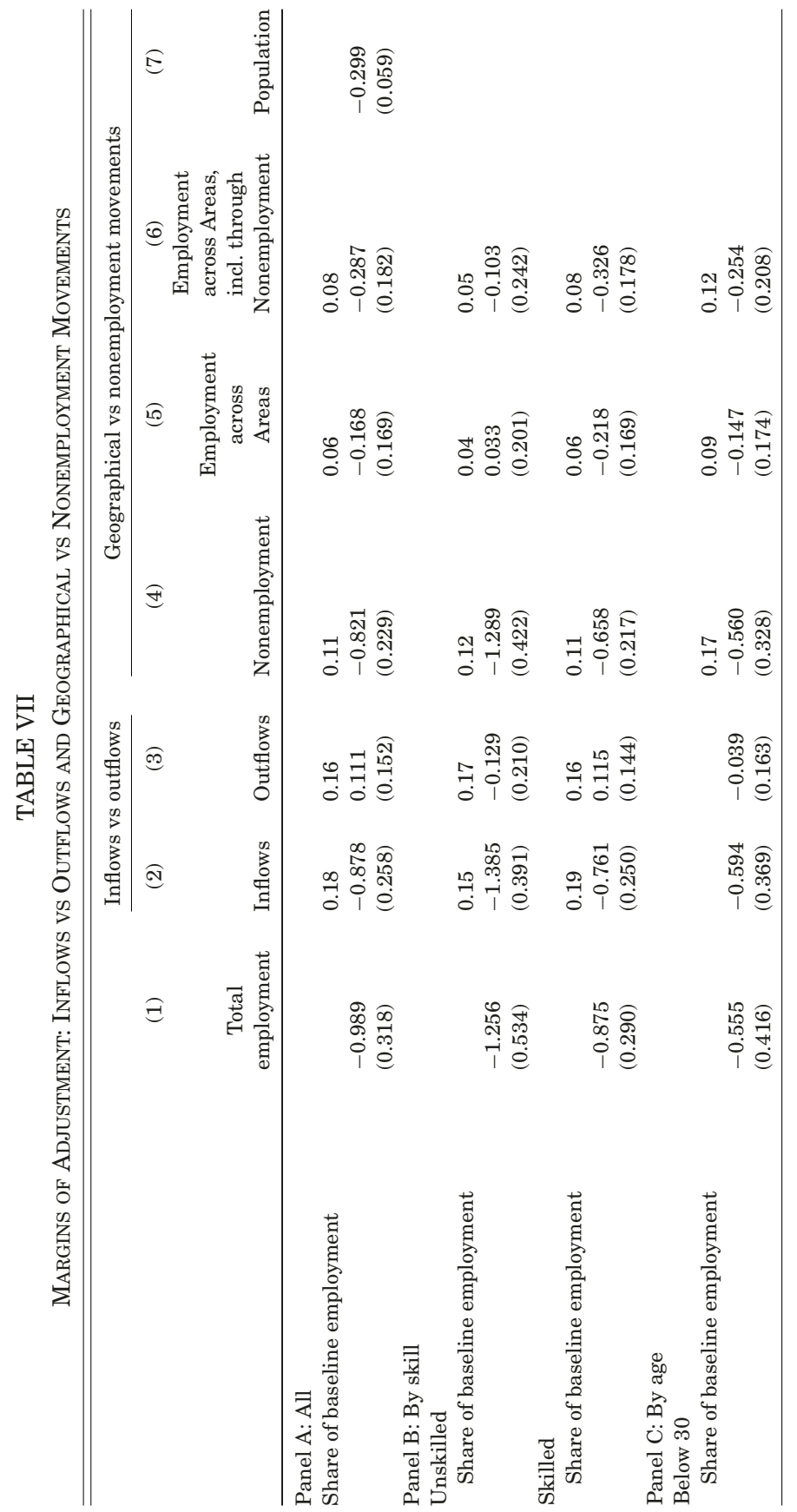




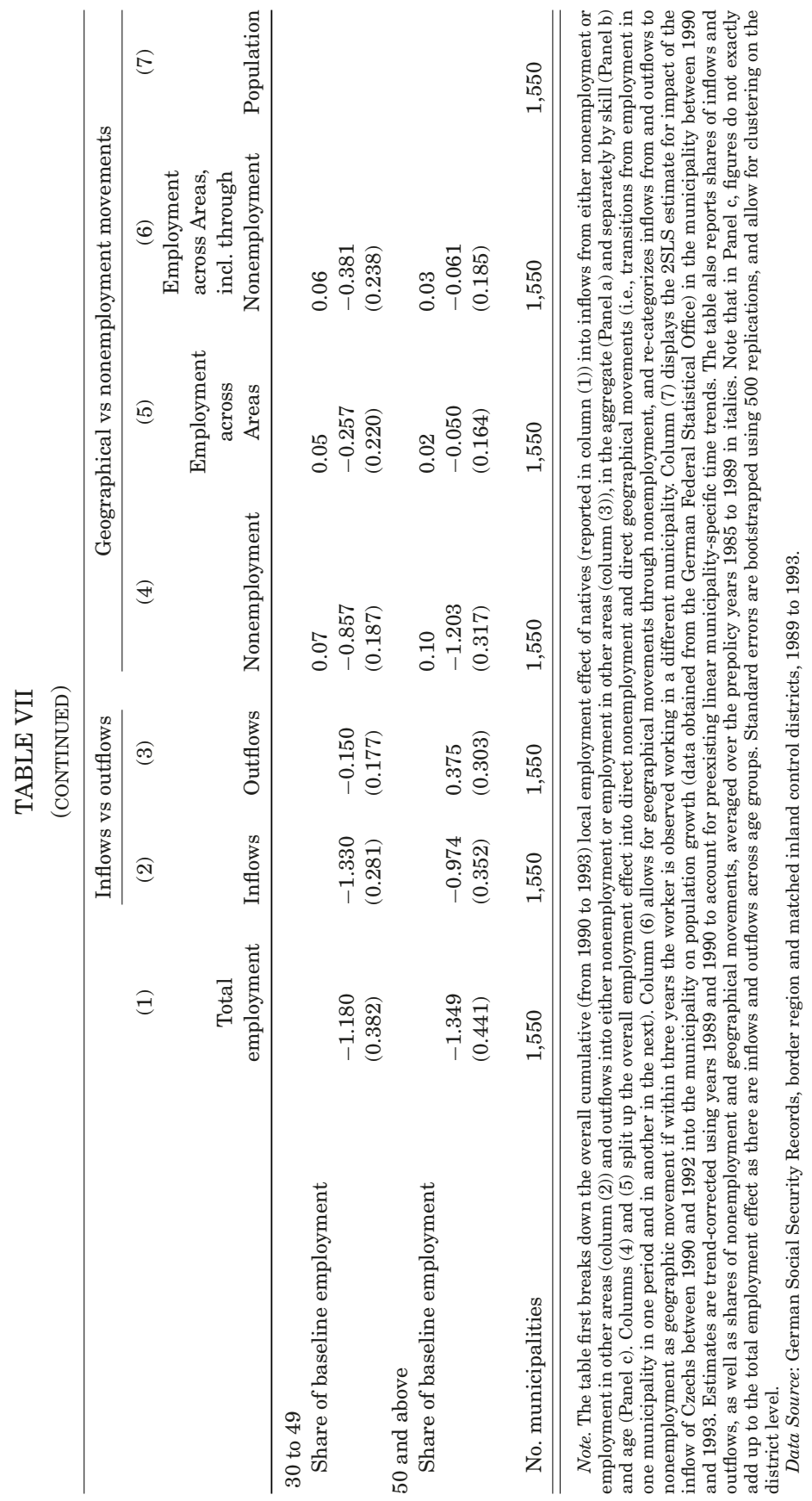


labor supply because they have outside alternatives (e.g., the ability to move to an unaffected area). An alternative explanation (and one in line with our arguments in Section II.B) is that, because of private contractual arrangements or labor market regulations, it is costly for firms to lay off their existing workforce. Firms can, however, immediately adjust their hiring behavior. Whichever the explanation, most of the burden of the employment effect is borne by outsiders, whose strong labor supply response shields employed or incumbent workers from the labor supply shock. ${ }^{35}$

2. Employment versus Nonemployment Movements. Another way to decompose the overall employment effect is to distinguish between movements from and to nonemployment (including movements from and to unemployment) and movements from and to employment in other areas. ${ }^{36}$ It should be noted that this distinction differs from changes in residency (which are not directly observed in our data), in that not all of the employmentto-employment movements across areas, and some of our nonemployment movements, may entail a change in residency.

We report the decomposition in columns (4) and (5) of Table VII, defining a transition as an employment movement if the worker is employed in one municipality in the base period and in another municipality one year later. In terms of magnitude, movement from and to nonemployment is far more relevant than movement across areas: only about $17 \%\left(\frac{-0.168}{-0.989}\right)$ of the overall employment effect results from direct employment movement to and from other areas, with the remaining $83 \%$ stem from movement into and out of nonemployment (see Panel a).

These entries, however, consider only direct movement in which the worker was employed in two consecutive years in different municipalities. But workers might find employment in another area only after a spell of nonemployment, meaning that the numbers in column (5) could underestimate the extent of employment movements to other areas. To investigate this possibility, we categorize inflows from and outflows to nonemployment

35. A related point is made by Cadena and Kovak (2016).

36. That is, $\frac{L_{g t}^{N}-L_{g t-1}^{N}}{L_{g t-1}^{N}}=\frac{\operatorname{In}_{g}^{E}-\mathrm{Out}_{g}^{E}}{L_{g t-1}^{N} 1_{\text {employment }}}+\frac{\mathrm{In}_{g}^{N E}-\mathrm{Out}_{g}^{N E}}{L_{g t-1}^{N E} \text { non-employment }^{N}}$, where $\operatorname{In}_{g}^{E}$ are inflows from employment in other areas, $\operatorname{In}_{g}^{N E}$ are inflows from nonemployment, Out ${ }_{g}^{E}$ are outflows into employment in other areas and $\mathrm{Out}_{g}^{N E}$ are outflows into nonemployment. 
as an employment movement from or to another area if within three years (as opposed to the previous or next year, as in column (5)) the worker is observed working in a different municipality. ${ }^{37}$ This redefinition increases the estimated importance of geographic movement, which now rises from $17 \%$ (column (5)) to close to $29 \%$ (column (6)) of the overall employment effect. Interestingly, a further decomposition of employment movements into inflows and outflows shows that most employment movements are driven by a reduction in inflows, with outflows to employment in other areas being negligible (see Table VIII). Thus, while we do find employment movements to other areas in response to the labor supply shock, our results also indicate that these are not induced by individuals in affected areas seeking employment in unaffected areas (as usually suggested in the literature, see Peri and Sparber 2011 for a review), but by individuals not seeking employment in affected areas. Spatial arbitrage in response to local shocks may thus be achieved through a reduction rather than an increase in geographical mobility (if individuals who would have found employment in the affected area if the shock had not happened stay in their area instead). This pattern is consistent with recent evidence on internal migration rates in the U.S. during the Great Recession (see Monras 2015b).

Finally, in column (7) of Table VII, we directly investigate how the municipality's population responds to the Czech inflow using population counts from Germany's Federal Statistical Office. These data are informative about changes in residency in response to an immigration-induced labor supply shock, rather than about employment in other areas analyzed so far, albeit not broken down by age or skill. The results indicate that a 1 percentage point increase in the employment share of Czech commuterswho do not live in the affected German border region-decreases local population levels by $0.3 \%$. Thus, the estimation of the employment effects would have been roughly $30 \%$ smaller if, as in much of the extant literature, we had measured them as changes in the employment-to-population ratio. Using the change in employment-to-population ratio in the municipality as our dependent variable, we obtain a coefficient of -0.611 (as opposed to -0.926 in our baseline specification), with a standard error of 0.217 .

37. Even if we increase the time window to five years, the numbers are similar. 


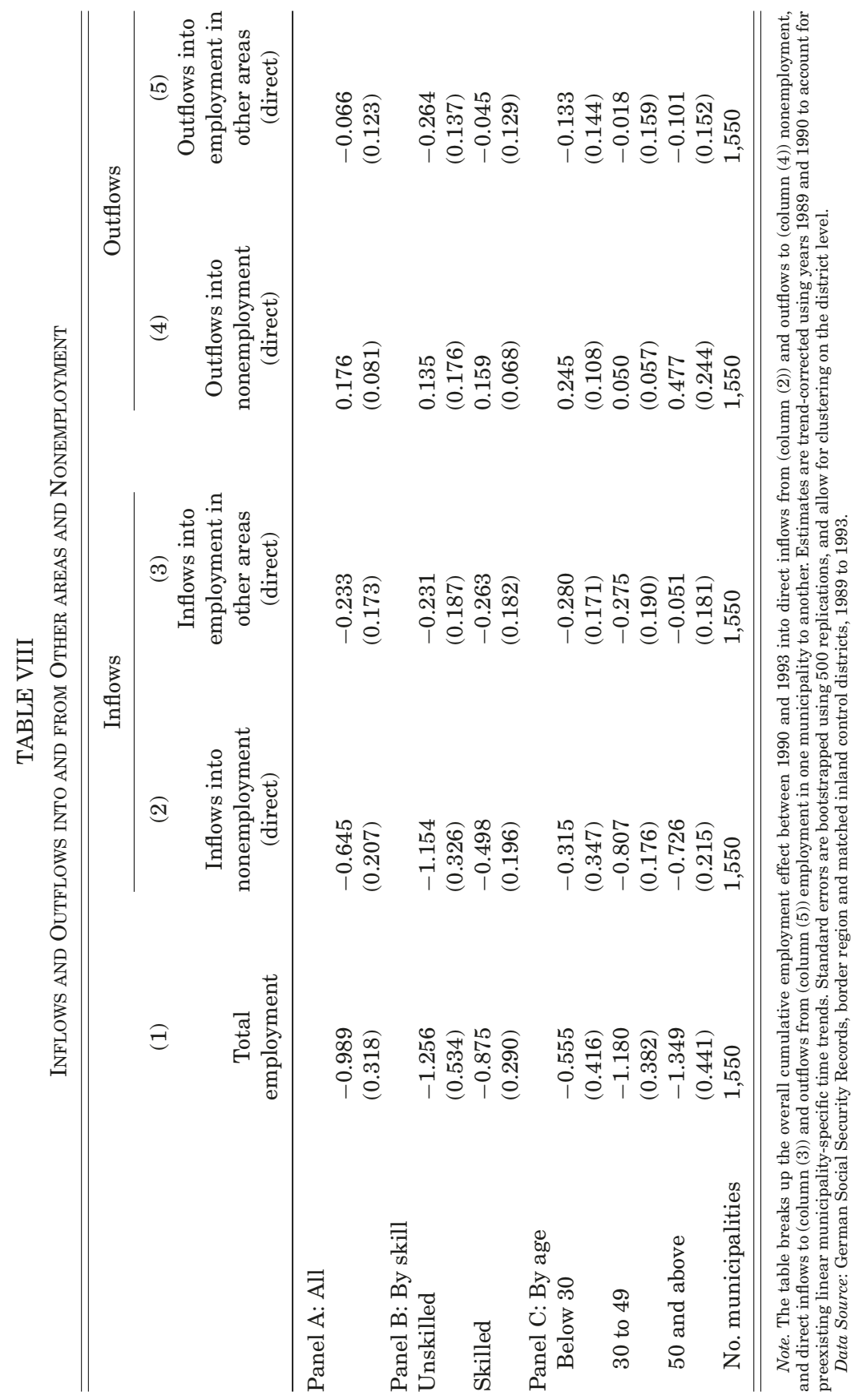


3. Employment versus Nonemployment Movement by Skill and Age. The relative importance of employment movements across areas differs markedly between skill and age groups. Whereas for unskilled workers, the entire employment effect is due to movement into and out of nonemployment, for skilled workers, between $25 \%$ and $37 \%$ of the overall employment response involves employment movement across areas. This mirrors the larger geographical mobility rates for skilled than unskilled workers observed in our (see Panel b of Table VII) and other data (see, e.g., Amior 2015). Differentiating between age groups in Panel c of Table VII indicates that employment movements across areas are relatively more important for workers under 30 who experience the smallest absolute employment effect $\left(27 \%, \frac{-0.147}{-0.555}\right.$, columns (4) and (5)). For workers over 50, in contrast, for whom the absolute employment effect is largest, nearly all the labor supply shock is absorbed through transitions into and out of nonemployment-as we would expect if older workers are entitled to generous unemployment benefits and can take advantage of early retirement packages.

\section{Discussion And Conclusions}

Exploiting a commuting policy that created a sharp, sudden, and unexpected inflow of Czech workers to areas along the German-Czech border, we assess the impact of an immigrationinduced labor supply shock on native wages and employment and identify response dynamics in the policy's immediate aftermath. Our results show that on average, the labor supply shock led to a moderate decline in local wages and a sharp decline in local employment-an effect that is nearly entirely accounted for by a reduction in hiring, and not by an increase in separations. This observation indicates that "outsiders" (in particular, nonemployed workers) bear most of the burden of the labor supply shock and thus shield "insiders" (i.e., workers employed in the affected area) from the adverse effects of the immigration-induced labor supply shock.

Interestingly, the overall patterns of adjustment to the immigration-induced labor supply shock documented in this paper closely mirror the labor market adjustments in a recession: The business cycle literature highlights that in a recession wages in ongoing jobs are relatively sticky whereas employment drops sharply, which-just like in our case-is mostly accounted for by 
reduced hiring and not by increased separations (e.g., Hall 2005; Shimer 2005; Rogerson and Shimer 2011; Shimer 2012). This suggests our findings have implications beyond the immigration literature and generally help us to better understand how labor markets respond to shocks.

It is important to emphasize that we focus on the short-term effects of an immigration-induced labor supply shock, which may be more pronounced than the longer-term effects typically considered in the literature. For instance, wages may be partially downward rigid in the short but not in the longer term, while the supply of capital may be more responsive-especially if, as in our case, the inflow of immigrants was unexpected. In the longer term, firms and workers could also respond to an immigrationinduced labor supply shock along other dimensions not considered here. For instance, firms might change their technology (see, e.g., Lewis 2011), labor market entrants might invest more in fulltime education (see, e.g., Hunt 2012 and Smith 2012), and even experienced workers might upgrade to more skilled occupations (Peri and Sparber 2009). However, the short-term responses that we investigate here shape agents' incentives to undertake such investments, and are therefore crucial to understand and assess the mechanisms behind any longer-term adjustment.

University College London and Centre for Research and ANALYSIS OF MigRation

University College London and Centre for Research AND ANALYSIS OF MigRATION

Universidad CARLOS III DE MADRID AND CENTRE FOR RESEARCH AND ANALYSIS OF MigRATION

\section{SuPPlementary Material}

An Online Appendix for this article can be found at The Quarterly Journal of Economics online.

\section{REFERENCES}

Abadie, Alberto, Alexis Diamond, and Jens Hainmueller, "Synthetic Control Methods for Comparative Case Studies: Estimating the Effect of California's Tobacco Control Program," Journal of the American Statistical Association, 105 (2010), 493-505. 
Abadie, Alberto, and Javier Gardeazabal, "The Economic Costs of Conflict: A Case Study of the Basque Country," American Economic Review, 93 (2003), 113132.

Altonji, Joseph G., and David Card, "The Effects of Immigration on the Labor Market Outcomes of Less-Skilled Natives," In Immigration, Trade, and the Labor Market, edited by John M. Abowd and Richard B. Freeman. Chicago: University of Chicago Press (1991).

Amior, Michael, "Why Are Higher Skilled Workers More Mobile Geographically? The Role of the Job Surplus," London: Mimeo, Centre for Economic Performance, 2015.

Angrist, Joshua D., "Short-Run Demand for Palestinian Labor," Journal of Labor Economics, 14 (1996), 425-453.

Angrist, Joshua D., and Alan Krueger, "Empirical Strategies in Labor Economics," in Handbook of Labor Economics, Vol. 3A, edited by Orley Ashenfelter and David Card (Amsterdam: Elsevier, 1999).

Angrist, Joshua D., and Adriana D. Kugler, "Protective or Counterproductive? Labour Market Institutions and the Effect of Immigration on EU Natives," Economic Journal, 113 (2003), F302-F331.

Aydemir, Abdurrahman, and George J. Borjas, "Attenuation Bias in Measuring the Wage Impact of Immigration," Journal of Labor Economics, 29 (2011), 69-113.

Aydemir, Abdurrahman, and Murat G. Kirdar, "Employment Effects of a Large Burst of Immigration: Improving Plausible Exogeneity of an IV via Treatment and Comparison Group Matching," (Istanbul: Mimeo, Sabanci University, 2014).

Blanchard, Olivier, and Lawrence Katz, "Regional Evolutions," Brookings Papers on Economic Activity, 23 (1992), 1-75.

Blundell, Richard, Antoine Bozio, and Guy Laroque, "Extensive and Intensive Margins of Labour Supply: Work and Working Hours in the US, the UK and France," Fiscal Studies, 34 (2013), 1-29.

Borjas, George J., "The Economic Analysis of Immigration," in Handbook of Labor Economics, Vol. 3A, edited by Orley Ashenfelter and David Card (Amsterdam: Elsevier, 1999).

Borjas, George J., "The Labor Demand Curve is Downward Sloping: Reexamining the Impact of Immigration on the Labor Market," Quarterly Journal of Economics, 118 (2003), 1335-1374.

Borjas, George J., "Native Internal Migration and the Labor Market Impact of Immigration," Journal of Human Resources, 41 (2006), 221-258.

Borjas, George J., "The Analytics of the Wage Effect of Immigration," IZA Journal of Migration, 2 (2013), 22.

Borjas, George J., Richard B. Freeman, and Lawrence F. Katz, "Searching for the Effect of Immigration on the Labor Market," American Economic Review, 86 (1996), 246-251.

Borjas, George J., Richard B. Freeman, and Lawrence F. Katz, "How Much Do Immigration and Trade Affect Labor Market Outcomes?," Brookings Papers on Economic Activity, 28 (1997), 1-90.

Boustan, Leah P., Price V. Fishback, and Shawn Kantor, "The Effect of Internal Migration on Local Labor Markets: American Cities during the Great Depression," Journal of Labor Economics, 28 (2010), 719-746.

Bodvarsson, Örn B., Joshua J. Lewer, and Hendrik F. Van den Berg, "Measuring Immigration's Effects on Labor Demand: A Re-examination of the Mariel Boatlift," Labour Economics, 15 (2008), 560-574.

Bratsberg, Bernt, and Oddbjørn Raaum, "Immigration and Wages: Evidence from Construction," Economic Journal, 122 (2012), 1177-1205.

Butcher, Kristin F., and David Card, "Immigration and Wages: Evidence from the 1980's," American Economic Review (Papers and Proceedings), 81 (1991), $292-296$. 
Cadena, Brian C., and Brian K. Kovak, "Immigrants Equilibrate Local Labor Markets: Evidence from the Great Recession," American Economic Journal: Applied Economics, 8 (2016), 257-290.

Cameron, Colin A., Jonah B. Gelbach, and Douglas L. Miller, "Bootstrap-Based Improvements for Inference with Clustered Errors," Review of Economics and Statistics, 90 (2008), 414-427.

Card, David, "The Impact of the Mariel Boatlift on the Miami Labor Market," Industrial and Labor Relations Review, 43 (1990), 245-257.

Card, David, "Immigration and Inequality," American Economic Review, 99 (2009), $1-21$.

Card, David, "Immigrant Inflows, Native Outflows, and the Local Labor Market Impacts of Higher Immigration," Journal of Labor Economics, 19 (2001), 2264.

Card, David, 2007 "How Immigration Affects U.S. Cities," CReAM Discussion Paper No. 11/07.

Card, David, and John DiNardo, "Do Immigrant Inflows Lead to Native Outflows?," American Economic Review (Papers and Proceedings), 90 (2000), 360-367.

Card, David, Francis Kramarz, and Thomas Lemieux, "Changes in the Relative Structure of Wages and Employment: A Comparison of the United States, Canada, and France," Canadian Journal of Economics, 32 (1999), 843-877.

Card, David, and Thomas Lemieux, "Can Falling Supply Explain the Rising Return to College for Younger Men? A Cohort-Based Analysis," Quarterly Journal of Economics, 116 (2001), 705-746.

Carrington, William J., and Pedro J. de Lima, "The Impact of 1970s Repatriates from Africa on the Portuguese Labor Market," Industrial and Labor Relations Review, 49 (1996), 330-347.

Chetty, Raj, Adam Guren, Day Manoli, and Andrea Weber, "Are Micro and Macro Labor Supply Elasticities Consistent? A Review of Evidence on the Intensive and Extensive Margins," American Economic Review (Papers and Proceedings), 101 (2011), 471-475.

Cohen-Goldner, Sarit, and Daniele Paserman, "Mass Migration to Israel and Natives' Transitions from Employment," Industrial and Labor Relations Review, 59 (2006), 630-652.

Conley, Timothy G., "GMM Estimation with Cross Sectional Dependence," Journal of Econometrics, 92 (1999), 1-45.

Dao, Mai, Davide Furceri, and Prakash Loungani, "Regional Labor Market Adjustments in the United States," IMF Working Paper 14/211, 2014.

Dietz, Frido, Heinz Gommlich, and Werner Karr, IAB. "Ostdeutsche Arbeitskräfte in Westdeutschland," Mitteilungen aus der Arbeitsmarkt und Berufsforschung, 25 (1992), 499-518.

Doran, Kirk, Alexander Gelber, and Adam Isen, "The Effects of High-Skilled Immigration Policy on Firms: Evidence from H-1B Visa Lotteries," Institute for Research on Labor and Employment, IRLE Working Paper No. 117-15, 2015.

Dustmann, Christian, Francesca Fabbri, and Ian Preston, "The Impact of Immigration on the British Labour Market," Economic Journal, 115 (2005), F324F341.

Dustmann, Christian, Tommaso Frattini, and Ian Preston, "The Effect of Immigration along the Distribution of Wages," Review of Economic Studies, 80 (2013), $145-173$.

Dustmann, Christian, Tommaso Frattini, and Anna Rosso, "The Effect of Emigration from Poland on Polish Wages," Scandinavian Journal of Economics, 117 (2015), 522-564.

Dustmann, Christian, Johannes Ludsteck, and Uta Schöenberg, "Revisiting the German Wage Structure," Quarterly Journal of Economics, 124 (2009), 843881.

Dustmann, Christian, and Ian Preston, "Comment: Estimating the Effect of Immigration on Wages," Journal of the European Economic Association, 10 (2012), $216-223$. 
Fitzenberger, Berndt, Aderonke Osikominu, and Robert Völter, "Imputation Rules to Improve the Education Variable in the IAB Employment Subsample," Schmollers Yearbook: Journal of Applied Social Science Studies, 126 (2006), 405-436.

Filer, Randall, "The Effect of Immigrant Arrivals on Migratory Patterns of Native Workers," in Immigration and the Workforce: Economic Consequences for the United States and Source, edited by George J. Borjas and Richard B. Freeman (Chicago: University of Chicago Press, 1992).

Friedberg, Rachel M., "The Impact of Mass Migration on the Israeli Labor Market," Quarterly Journal of Economics, 116 (2001), 1373-1408.

Goldin, Claudia, "The Political Economy of Immigration Restriction in the United States, 1890 to 1921," in The Regulated Economy, edited by Claudia Goldin and Gary Libecap (Chicago: University of Chicago Press, 1994).

Glitz, Albrecht, "The Labour Market Impact of Immigration: Quasi-experimental Evidence," Journal of Labor Economics, 30 (2012), 175-213.

Greenwood, Michael J., and Gary L. Hunt, "Migration and Interregional Employment Redistribution in the United States," American Economic Review, 74 (1984), 957-969.

Grossman, Jean Baldwin, "The Substitutability of Natives and Immigrants in Production," Review of Economics and Statistics, 54 (1982), 596-603.

Hall, Robert E., "Job Loss, Job Finding, and Unemployment in the U.S. Economy over the Past Fifty Years," in NBER Macroeconomics Annual, Vol. 20, edited by Mark Gertler and Kenneth Rogoff (Cambridge, MA: MIT Press, 2005).

Hamermesh, Daniel S., Labor Demand (Princeton, NJ: Princeton University Press, 1993).

Hercowitz, Zvi, and Eran Yashiv, "A Macroeconomic Experiment in Mass Immigration," IZA Discussion Paper No. 475, 2002.

Hönekopp, Elmar, "Ost-West-Wanderungen: Die neuen Migrationsbewegungen," in Ausländer im vereinten Deutschland: Perspektiven der Ausländerpolitik (Bonn: Forschungsinstitut der Friedrich-Ebert-Stiftung, 1991).

Hunt, Jennifer, "The Impact of the 1962 Repatriates from Algeria on the French Labor Market," Industrial and Labor Relations Review, 45 (1992), 556-572.

Hunt, Jennifer, "The Impact of Immigration on the Educational Attainment of Natives," NBER Working Paper No. w18047, 2012.

Kline, Patrick, and Enrico Moretti, "Local Economic Development, Agglomeration Economies, and the Big Push: 100 Years of Evidence from the Tennessee Valley Authority," Quarterly Journal of Economics, 129 (2014), 275-331.

Kropp, Per, "Veränderungen der Pendlerverflechtungen in Deutschland zwischen 1993 und 2008," in Nationale und regionale Mobilität von Unternehmen und Arbeitnehmern, edited by Gabi Troeger-Weiß and Peter Jurczek (Nürnberg: Institut für Arbeitsmarkt- und Berufsforschung der Bundesanstalt für Arbeit, 2010).

Lewis, Ethan, "Immigration, Skill Mix, and Capital Skill Complementarity," Quarterly Journal of Economics, 126 (2011), 1029-1069.

Lichter, Andreas, Andreas Peichl, and Sebastian Siegloch, "The Own-wage Elasticity of Labor Demand: A Meta-regression Analysis," European Economic Review, 80 (2015), 94-119.

Llull, Joan, "Immigration, Wages, and Education: A Labor Market Equilibrium Structural Model," Barcelona GSE Working Paper No. 711, 2013.

MaCurdy, Thomas, "An Empirical Model of Labor Supply in a Life Cycle Setting," Journal of Political Economy, 89 (1981), 1059-1085.

Manacorda, Marco, Alan Manning, and Jonathan Wadsworth, "The Impact of Immigration on the Structure of Wages: Theory and Evidence from Britain," Journal of the European Economic Association, 10 (2012), 120-151.

Mansour, Hansi, "The Effects of Labor Supply Shocks on Labor Market Outcomes: Evidence from the Israeli-Palestinian Conflict," Labour Economics, 17 (2010), 930-939. 
Monras, Joan, "Immigration and Wage Dynamics: Evidence from the Mexican Peso Crisis," Sciences Po Economics Discussion Papers No. 2015-04, 2015a.

Monras, Joan, "Economic Shocks and Internal Migration," IZA Discussion Paper No. $8840,2015 b$.

Moritz, Michael, "The Impact of Czech Commuters on the German Labor Market," Prague Economic Papers, 20 (2011), 40-58.

Notowidigdo, Matthew J., "The Incidence of Local Labor Demand Shocks," (Chicago: Mimeo, University of Chicago, Booth School of Business, 2013).

Ottaviano, Gianmarco I. P., and Giovanni Peri, "Rethinking the Effect of Immigration on Wages," Journal of the European Economic Association, 10 (2012), $152-197$.

Peri, Giovanni, and Chad Sparber, "Task Specialization, Immigration, and Wages," American Economic Journal: Applied Economics, 1 (2009), 135-169.

Peri, Giovanni, and Chad Sparber, "Assessing Inherent Model Bias: An Application to Native Displacement in Response to Immigration," Journal of Urban Economics, 69 (2011), 82-91.

Piyapromdee, Suphanit, "The Impact of Immigration on Wages, Internal Migration, and Welfare," (Madison: Mimeo, University of Wisconsin-Madison, 2014).

Prantl, Susanne, and Alexandra Spitz-Oener, "Interacting Product and Labor Market Regulation and the Impact of Immigration on Native Wages," (Berlin: Mimeo, Humboldt University of Berlin, 2014).

Redding, Stephen, and Daniel Sturm, "The Costs of Remoteness: Evidence From German Division and Reunification," American Economic Review, 98 (2008), 1766-1797.

Rogerson, Richard, and Robert Shimer, "Search in Macroeconomic Models of the Labor Market," in Handbook of Labor Economics, Vol. 4A, edited by Orley Ashenfelter and David Card (Amsterdam: Elsevier 2011).

Saiz, Albert, "Immigration and Housing Rents in American Cities," in Journal of Urban Economics, 61 (2007), 345-371.

Shimer, Robert, "The Cyclical Behavior of Equilibrium Unemployment and Vacancies," American Economic Review, 95 (2005), 25-49.

Shimer, Robert, "Reassessing the Ins and Outs of Unemployment," Review of Economic Dynamics, 15 (2012), 127-148.

Smith, Christopher L., "The Impact of Low-Skilled Immigration on the Youth Labor Market," Journal of Labor Economics, 30 (2012), 55-89.

Wagner, Mathis, "The Heterogeneous Labor Market Effect of Immigration," CeRP Working Paper No. 93, 2010.

Werner, Heinz, IAB. "Beschäftigung von Grenzarbeitnehmern in der Bundesrepublik Deutschland," Mitteilungen aus der Arbeitsmarkt und Berufsforschung, 26 (1993), 28-35.

Yagan, Danny, "The Enduring Employment Impact of Your Great Recession Location," (Berkeley: Mimeo, University of California Berkeley, 2016). 